FINAL REPORT

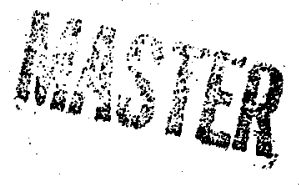

\title{
A REPORT ON PHASE I \\ ON THE \\ DEVELOPMENT OF IMPROVED SEALS AND BEARINGS \\ FOR DOWNHOLE DRILLING MOTORS
}

\author{
Submitted to \\ ERDA/Division of Geothermal Energy. \\ Washington, D.C. 20545 \\ Attention: Mr. Cliftón Carwile
}

Prime Contractor: Terra Tek

Subcontractor: Maurer Engineering, Inc.

Contract No. $E(10-1)-1581$

May, 1977

TR77-29
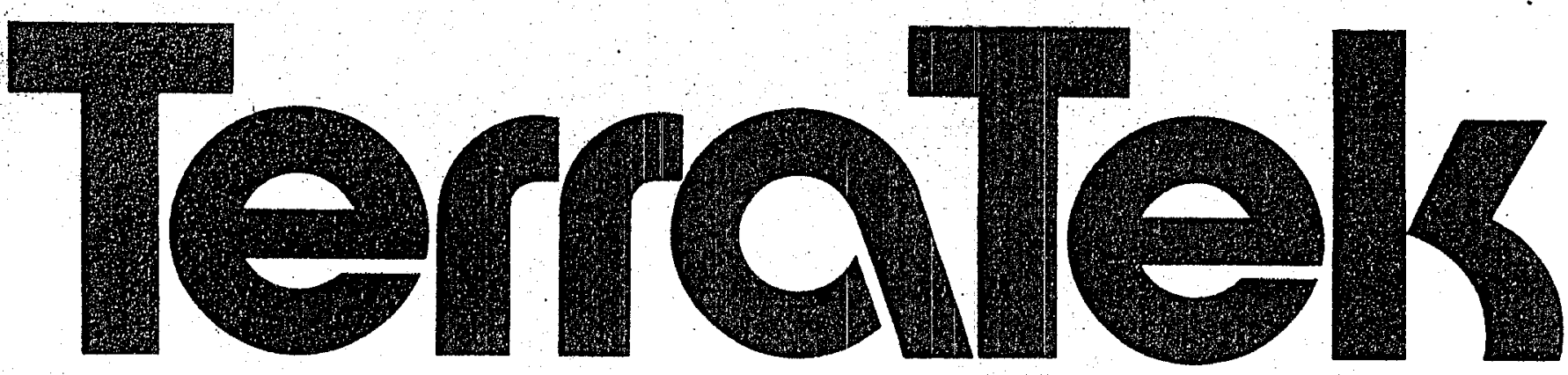


\section{DISCLAIMER}

This report was prepared as an account of work sponsored by an agency of the United States Government. Neither the United States Government nor any agency Thereof, nor any of their employees, makes any warranty, express or implied, or assumes any legal liability or responsibility for the accuracy, completeness, or usefulness of any information, apparatus, product, or process disclosed, or represents that its use would not infringe privately owned rights. Reference herein to any specific commercial product, process, or service by trade name, trademark, manufacturer, or otherwise does not necessarily constitute or imply its endorsement, recommendation, or favoring by the United States Government or any agency thereof. The views and opinions of authors expressed herein do not necessarily state or reflect those of the United States Government or any agency thereof. 


\section{DISCLAIMER}

Portions of this document may be illegible in electronic image products. Images are produced from the best available original document. 
FINAL REPORT

\title{
PROGRAM TO DEVELOP IMPROVED DOWNHOLE DRILLING MOTORS
}

\author{
Compiled by: Randy R. Nielsen \\ BY \\ (In Alphabetical Order) \\ Alan D. Black \\ Sidney J. Green \\ Larry W. Matson (Maurer Engineering) \\ William C. Maurer (Maurer Engineering) \\ Randy R. Nielsen \\ Jeddy D. Nixon (Maurer Engineering) \\ James G. Wilson
}

\section{FOR}

\section{ENERGY RESEARCH AND DEVELOPMENT ADMINISTRATION \\ DIVISION OF GEOTHERMAL ENERGY \\ Contract No. E(10-1)-1581 \\ Attention: Mr. Clifton Carwile}

Prime contractor: TERRA TEK, INC.

subcontractor: MAURER ENGINEERING, INC.

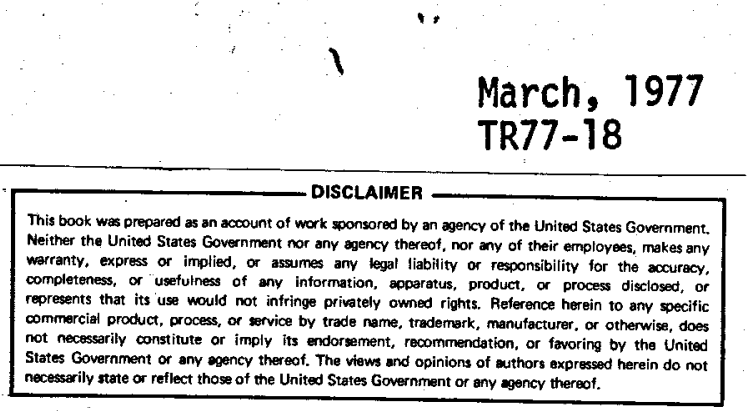




\section{FOREWORD}

This report summarizes the first-year effort on the ERDA/DGE Contract, $E(10-1)-1581$, "Program to Develop Improved Downhole Drilling Motors". This report completes Phase I of a proposed four-phase program aimed at developing seals and bearings for improving downhole drilling motors. The final goal is commercialization by industry of a significantly improved downhole mud drilling motor, capable of operating in geothermal environments.

It should be noted that meeting the objective of this program represents a substantial benefit, not only to geothermal energy resource recovery, but also to the oil-and-gas industry and to the mining industry as well. Improved downhole drilling motors would be highly beneficial for drilling of exploratory and production wells.

The first year's effort has not only successfully completed Phase I of this ERDA/DGE program, but has already helped to provide "stimulation" of industry development of a variety of geothermal downhole tools and equipment. For example, special rotary seals for high-temperature applications have and are being developed, and some oilfield equipment manufacturers have expanded their product development interests to include the higher temperatures associated with geothermal applications. The program has helped to clarify conditions found in geothermal applications 
including formation temperature and bottom-hole temperature estimates. Test and evaluation capabilities for new as well as conventional downhole motor seals have been developed and a joint program with industry is underway to develop and test new seals in Phase II. Data will be transmitted to the petroleum equipment manufacturing industry as it becomes available to assist them in upgrading their products. This entire program is geared so that knowledge gained can be rapidly transmitted to these manufacturers to aid their research and development efforts. 


\section{TABLE OF CONTENTS}

$\begin{array}{lr}\text { FOREWORD } & i \mathbf{i} \\ \text { TABLE OF CONTENTS } & i i i \\ \text { INTRODUCTION } & 1 \\ \text { BACKGROUND OF DOWNHOLE MOTOR DEVELOPMENT } & 3 \\ \text { NEW DRILLING MOTOR CONCEPTS (Maurer Engineering) } & 7 \\ \text { ERDA BEARING PACK (Maurer Engineering) } & 17 \\ \text { CANDIDATE SEALS (Maurer Engineering) } & 23 \\ \text { BEARING APPLICATION (Maurer Engineering) } & 33 \\ \text { SEAL TESTER DESIGN DETAILS } & 37 \\ \text { SEAL-BEARING PACKAGE TEST STAND } & 49 \\ \text { CONCLUSIONS } & 55 \\ \text { BIBLIOGRAPHY AND REFERENCES } & 57\end{array}$


Radial Piston Motor with Stationary Cylinder Block

Radial Piston Motor with Rotating Cylinder

Block

Ball Radial Piston Motor

Cam-Type Piston Motor

Scalloped Radial Piston Motor

In-Line Axial Piston Motor

Bent-Axis Axial Piston Motor

Rotary Piston Pump

Rotary Spur Gear Motor

Crescent Gear Motor

Screw-Type Gear Motor

Internal Gear Motor

Rolling Internal Gear Motor 13

Moineau Gear Motor

Dyna-Drill Moineau Motor

Sliding Vane Motor

Lobe Type Sliding Vane Motor

Rolling Vane Motor

Flexing Vane Motor

Dyna-Drill Motor

New ERDA Bearing Pack

Bayou City Rubber Chevron Packing Seal

Engineering Enterprises Chevron Packing Seal

Utex Conventional Radial Lip Seal

Utex Canted Radial Lip Seal

Comparison of Seal Retention Force at 31 $500^{\circ} \mathrm{F}$

Schematic of the Seal Test Vessel

Simplified Cross-Section of the Rotary Shaft

The Downhole Motor Seal Test Facility

The Seal-Bearing Package Test Stand

Materials Use in Johns-Manville Uneepac Seals 


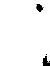




\section{INTRODUCTION}

In order to successfully develop geothermal energy sources, it is necessary to drill wells to allow the heat energy to be brought to the surface. However, the lack of downhole tools specifically designed for the environments encountered in geothermal drilling has proven to be a severe handicap in the drilling and completion of high temperature wells. Currently, it costs about twice as much to drill a geothermal well as it does to drill a comparable oil or gas well.

There is a need for improved geothermal drilling tools, but because of the relatively limited market and the uncertainty of future geothermal drilling programs, the drilling equipment manufacturers are not willing to spend large sums to develop special geothermal tools. Hence, the lack of effective tools is limiting the recovery of geotherma 1 energy.

This report details the results of the first year's effort on ERDA Contract No. E(10-1)-1581, "Program to Develop Improved Downhole Motors". Although this program is directed specifically at developing improved downhole motors for geothermal use, it has broad application to a variety of downhole tools. These other applications have resulted because of the emphasis on developing improved seals and bearings for downhole motors. High temperature seals, for example, might well be adapted for high-temperature, sealed bearing drill bits or high temperature packers. High-temperature seals and bearings are correspondingly 
needed for downhole geothermal well pumps.

The object of this effort is to provide broad test data, new designs, and sophisticated test and evaluation capabilities that are needed to develop improved downhole tools. This report outlines new bearing and seal designs, as well as the progress made on developing test facilities for full-size bearing and seal assemblies. 
BACKGROUND

\section{DOWNHOLE MOTORS}

Downhole drilling motors were first extensively tested in the 1920's. They did not find widespread use until the 1950's when turbodrills began to be used in the Soviet Union. By the early 1960's, 85 percent of the wells in the Soviet Union were being drilled with turbodrills. At present, this has decreased to about 70 percent because conventional drills are now being used in most Soviet Union wells deeper than 4,000 meters. Motors are not used in deep drilling because of the increased trip time required to replace worn turbodrills. In addition, some Dyna-Drill type motors are now being used in the Soviet Union which further reduces the number of holes drilled with turbodrills.

Drill motors have found widespread use in the United States for drilling directional holes, but they are not widely used for straight hole drilling because of bearing and seal problems. Current seal designs limit pressure drops to only 100 to 300 psi across the drill bit which is far below the 1,000 to 2,000 psi typically required for good bottomhole cleaning. Current bearings are also a limitation in that they are short-lived in high temperature environments, particularly when exposed to drilling muds rather than lubricants. Hence, bit weights and mud flow rates both must be reduced from optimum conditions as concessions to using a downhole motor. 
Rotary speeds of current motors are also a problem since commerical downhole motors operate at speeds of 300 to 1,000 RPM. Roller bits operate most effectively between speeds of 50 and 150 RPM. At high RPM and geothermal temperatures, roller-bit bearings fail after as few as five hours; whereas at lower speeds and controlled conditions, the bit bearings can last up to 200 hours. High rotary speeds also cause motor bearing failures in 20 to 40 hours* even at relatively modest well temperatures. This life expectency is not adequate to compete economically with conventional straight hole drilling.

Improvements to downhole motors could make these tools economically superior to conventional drilling practices. Probably the most significant factor in influencing economics is penetration rate. Considering this, improvements should be directed toward building a downhole motor capable of increasing the penetration rate by operating at optimum RPM and bit weights for diamond bits, as well as at low RPM, high bit weights and high pressure drops across the bit for roller bits. Higher torque capacity would also be required for roller bits. It should be noted here that several bit companies are working on higher speed roller bits (200 to $300 \mathrm{RPM})$. These bits would affect downhole motor drilling economics very positively if they are successfully developed.

It has been determined that by increasing the rotary speed of a bit the penetration rate will increase more than a corresponding percentage. When bit weight is increased, the penetration rate increases

* Extensive industry experience has proven the short life expectancy of the downhole motor bearings. Dyna-Drill, which is basically a good downhole motor has stator life of 300-600 hours, and typical bearing life in oil and gas wells of 20-30 hours even at bit loads of only $1 / 3$ to $1 / 4$ that of rotary drilling. Turbines may run 20-40 hours, or sometimes as low as 8.5 hours, as did the Engineering Enterprises last test motor. 
exponentially. A combination of reasonable improvements in both RPM (dependent upon higher speed roller bits or diamond bits) and bit weight (dependent upon the drilling motor thrust bearings) could lead to an increase of 40-70 percent in penetration rates. If both penetration rates and life can be significantly improved, the economics look extremely favorable for using downhole motors for straight hole drilling as well as for deviated hole drilling.

To be considered economically feasible, an improved downhole drilling motor should meet the following requirements (for general drilling): (1) operate at speeds of 100 to 200 RPM; (2) allow bit pressure drops of 1,000 to $2,000 \mathrm{psi}$; (3) have bearing life in excess of 200 hours; and for geothermal applications, (4) operate at bottomhole temperatures of $250^{\circ} \mathrm{F}$ and static soak temperatures of $250^{\circ} \mathrm{F}-500^{\circ} \mathrm{F}$ (depending on the time). Such a motor would find widespread use in deep wells and offshore wells. In addition, the commercialization of borehole data telemetry systems will increase the use of drilling motors since these systems will perform real time monitoring of the downhole drilling variables and will guide the motors in directional wells.

Phase I of this project had four main objectives:

1. The design and development of a lubricated bearing package with a minimum 1 ife expectency of 200 hours;

2. The development of improved rotary seals that will allow pressure drops across the bit in excess of 1,000 psi;

3. The design and fabrication of the necessary equipment to systematically evaluate seals, bearings, lubricants and packages under simulated downhole conditions;

4. The determination of the feasibility of new positive-displacement and other downhole motor concepts.*

* Semi-Annual Report, "Program to Develop Improved Downhole Drilling Motors, ERDA/DGE, Terra Tek Report TR76-59, November, 1976. 
The equipment developed in Phase I and detailed later in this report, will allow direct comparative testing of candidate seals and bearings acquired during this period. The test systems allow relatively quick turnaround time in evaluating many seal and bearing designs and configurations, and numerous variations in parameters. The process of comparing and evaluating new seals and bearing designs would be extremely tedious, time consuming and expensive (if not impossible) if attempted in actual commercial drilling. Hence, the test systems developed will provide a reasonable, controlled screening process for proposed improvements. 


\section{NEW DRILLING MOTOR CONCEPTS}

There are three basic types of motors that could be utilized as new downhole drilling motors:
- Piston
- Gear
- Vane

These are all positive displacement motors which rotate at a given speed for a given flow rate.

PISTON MOTORS

There are three basic types of piston motors:

- Radial Piston

- Axial Piston

- Rotary Piston

The radial piston motors may have a stationary cylinder block where the pistons cause the cam to rotate in an eccentric motion as shown in Figure 1 , or a rotating cylinder block where the cylinder block rotates in an eccentric fashion as shown in Figure 2.

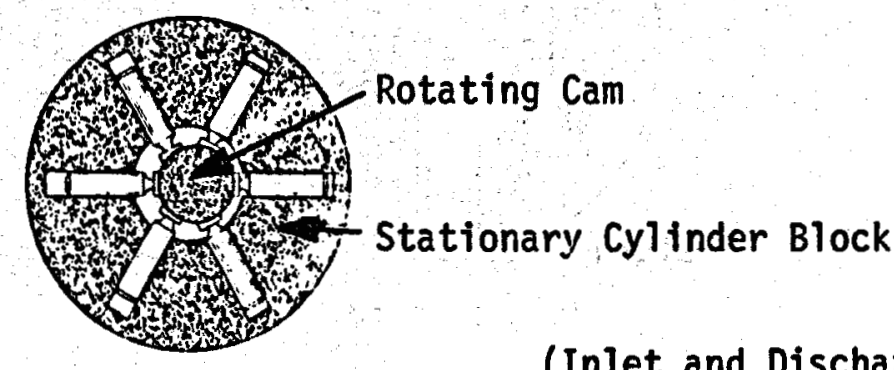

(Inlet and Discharge Valves are not shown)

FIGURE 1

RADIAL PISTON MOTOR WITH STATIONARY CYLINDER BLOCK 


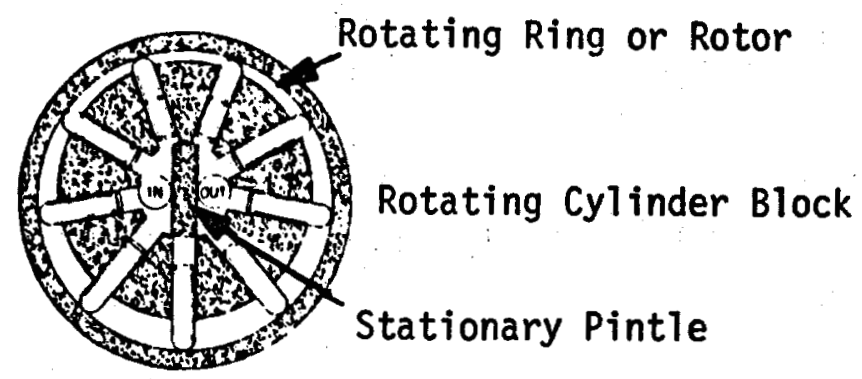

FIGURE 2

RADIAL PISTON MOTOR WITH ROTATING CYLINDER BLOCK

The ball radial motor shown in Figure 3 has rolling contact, but it has the disadvantage that sealing occurs along a line contact instead of over the entire length of the piston.

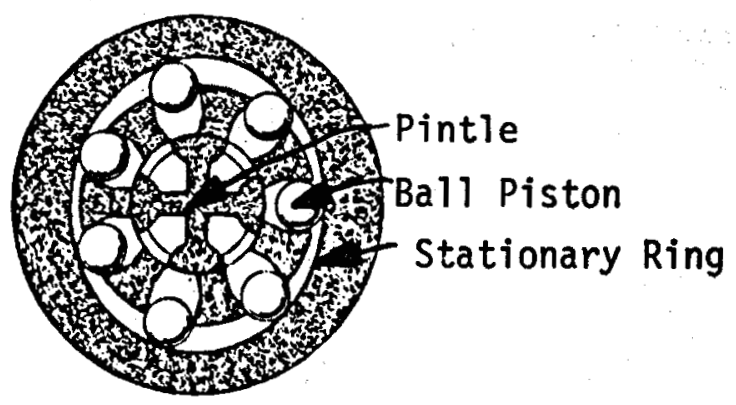

FIGURE 3

BALL RADIAL PISTON MOTOR

The cam type radial piston motor utilizes passageways through the pistons to valve fluid flow to the cylinders in the proper sequence.

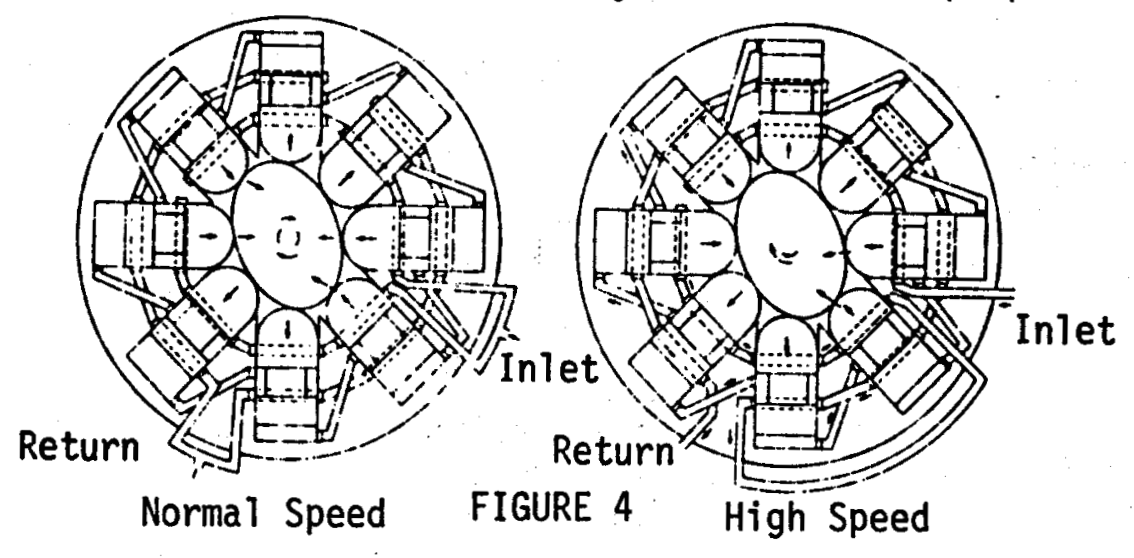

CAM-TYPE RADIAL PISTON MOTOR 
The radial piston motor shown in Figure 5 utilizes a scalloped contoured cam to provide rotation.

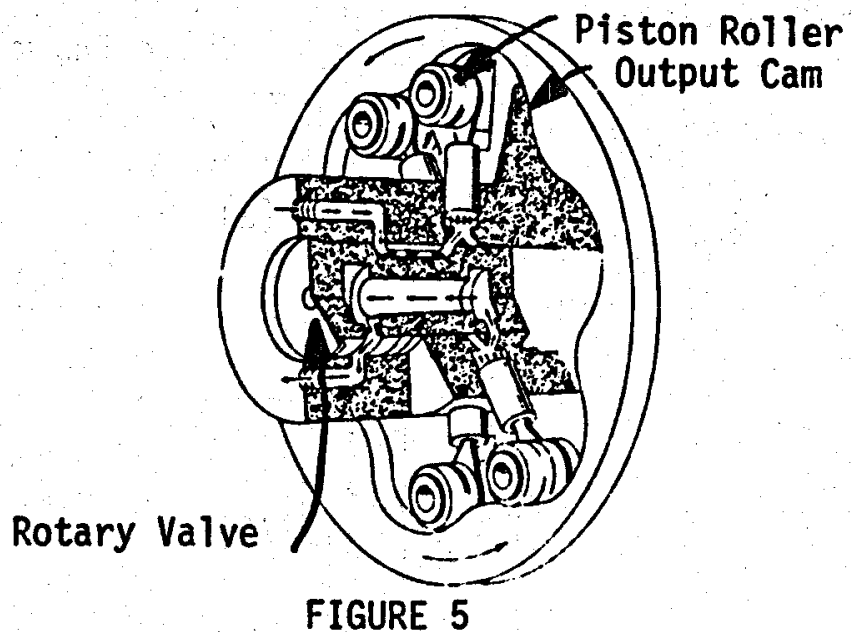

SCALLOPED RADIAL PISTON MOTOR

With in-line axial piston motors, the cylinder block is in line with the drive shaft as shown in Figure 6 . The pistons act on a cam plate to provide rotation to the drive shaft.

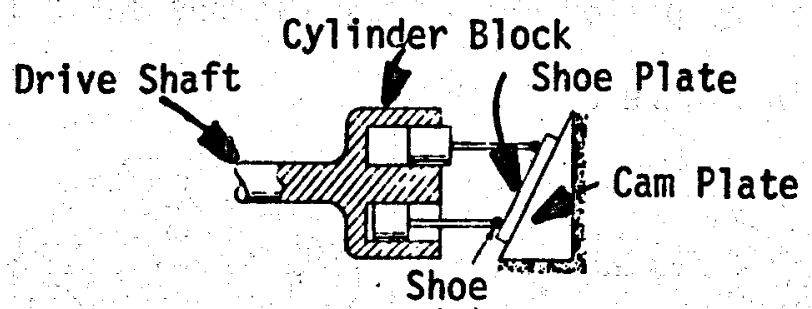

(a)

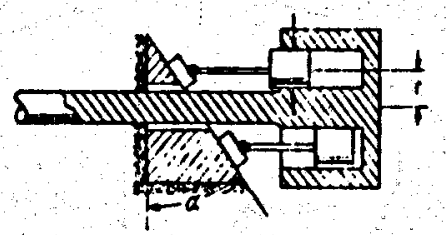

(b)

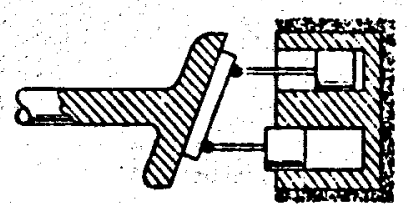

(c)

FIGURE 6

IN-LINE AXIAL PISTON 
With bent-axis axial piston motors, rotation is produced by tilting the pistons with respect to the drive shaft as shown in Figure 7.
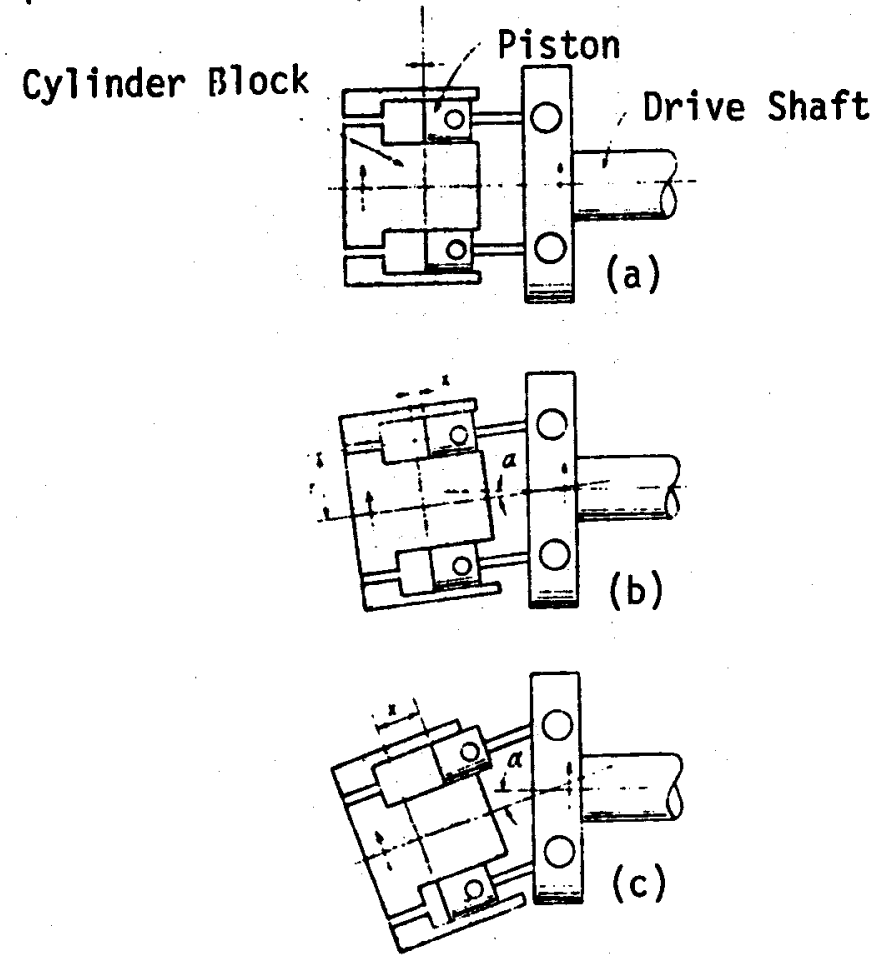

FIGURE 7

\section{BENT-AXIS AXIAL PISTON MOTOR}

In the rotary piston motor, two pistons seals against a rotating valve as shown in Figure 8.

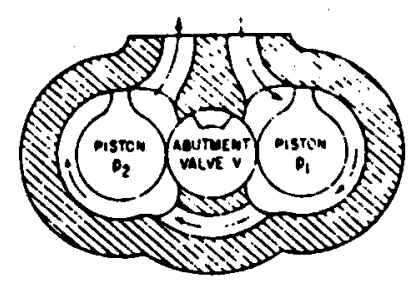

(a)

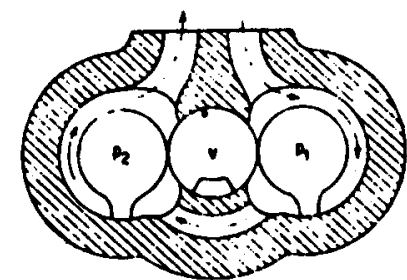

(c)

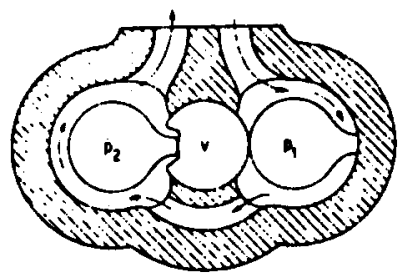

(b)

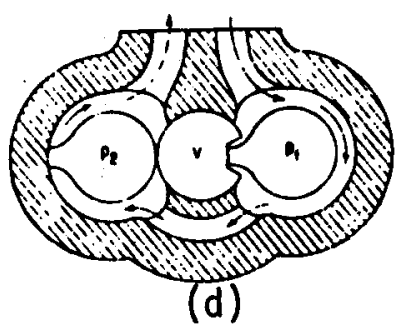

(d)

FIGURE 8

ROTARY PISTON MOTOR 
Although piston motors can produce high torques at low speeds, they are not good candidates for use as downhole drilling motors because they cannot tolerate abrasives in the hydraulic fluid. Drilling mud is highly abrasive, often containing up to 8 percent sand, and these abrasives would quickly erode the sealing surfaces and cause excessive leakage around the pistons.

\section{GEAR MOTORS}

There are several different types of gear motors. The first is the external spur gear motor where the gears seal against each other and against the housing. The driver and fdler gears are rotated as fluid is pumped through the motor as shown in Figure 9.

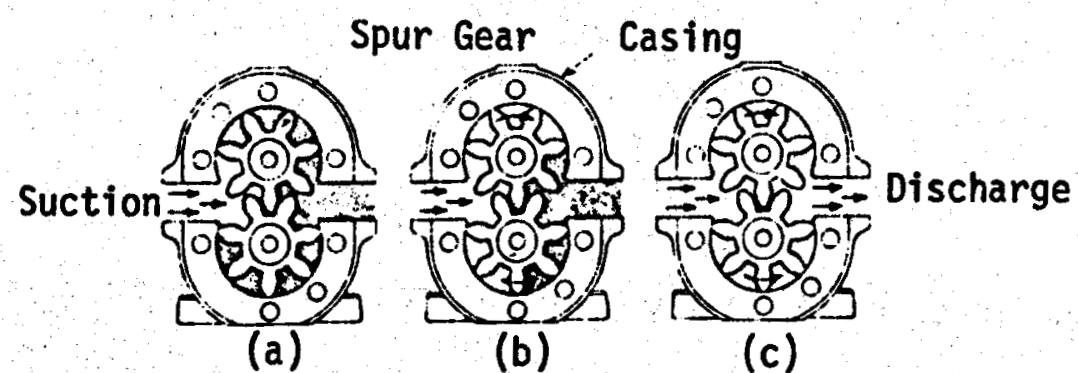

FIGURE 9

ROTARY SPUR GEAR MOTOR

The internal gear motor shown in Figure 10 utilizes a stationary inner gear which seals against a stationary crescent between the gears. As fluid is pumped through the motor, it acts over a larger area on one side of the outer gear, thereby forcing it to rotate. 


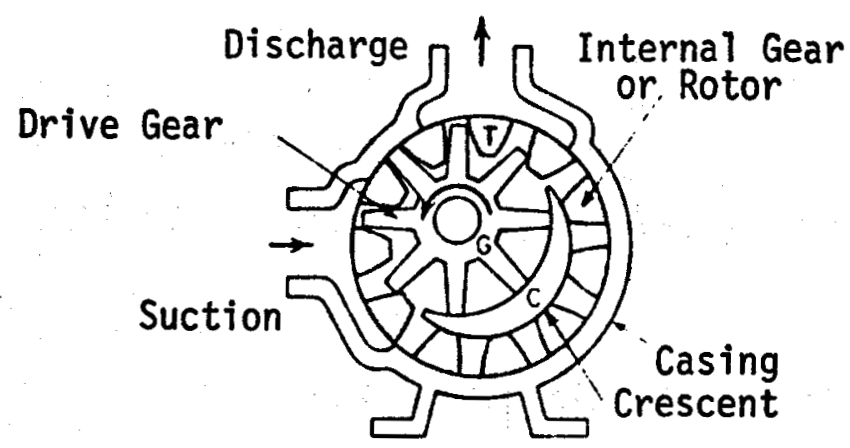

FIGURE 10

CRESCENT GEAR MOTOR

Screw-type gear motors have two or more screws which mesh to form fluid-tight seals as shown in Figure 11.

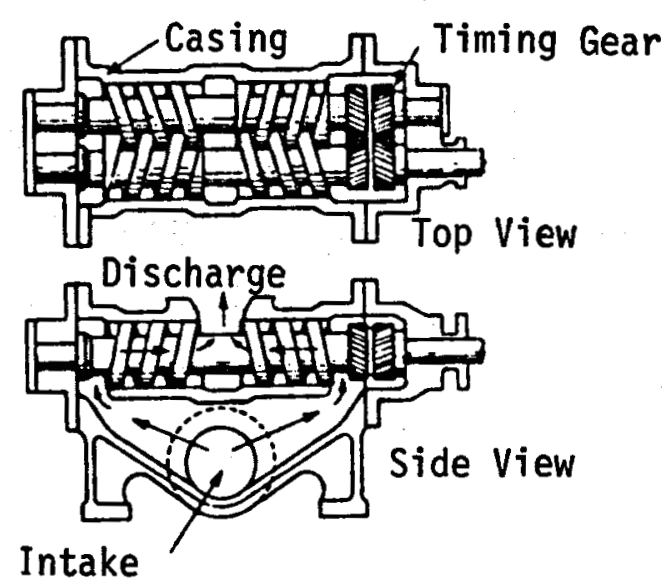

FIGURE 11

\section{SCREW-TYPE GEAR MOTOR}

The inner rotor in the internal gear motor shown in Figure 12 is forced to move along an eccentric path or orbit as fluid is pumped through the motor. Because of the eccentric motion, this motor requires the use of universal joints between the rotor and the motor output shaft.

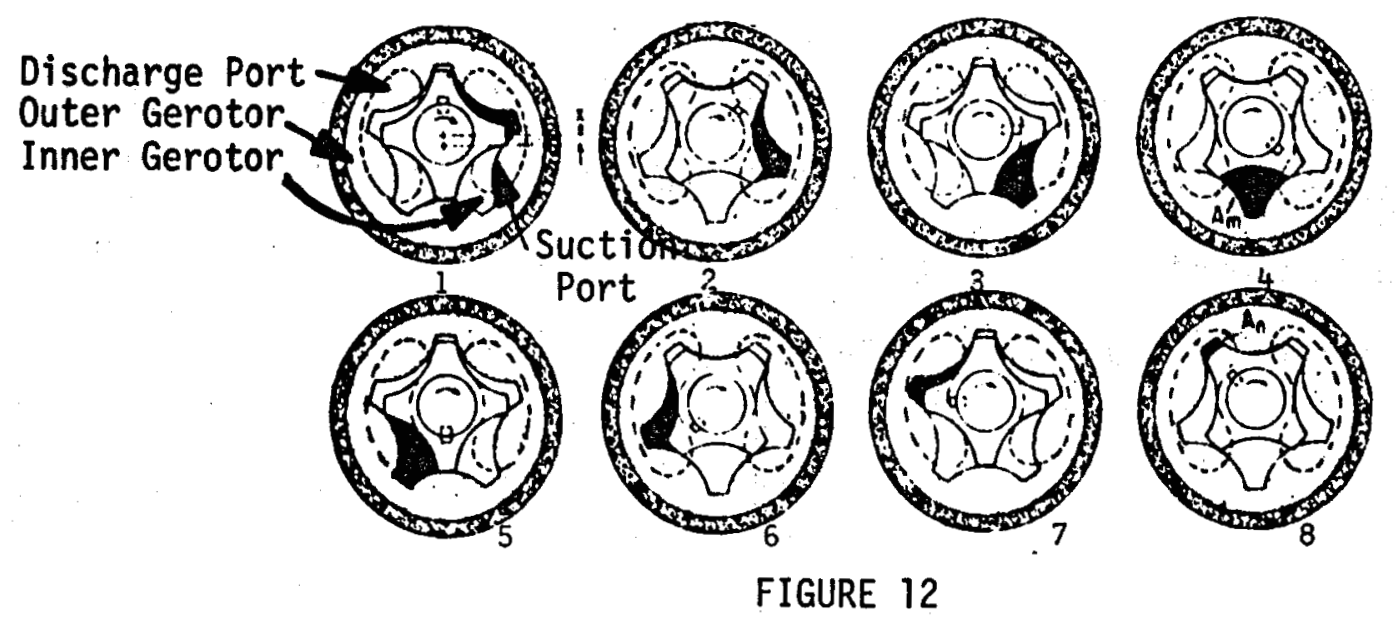

INTERNAL GEAR MOTOR 
The rolling vane gear motor shown in Figure 13 was designed to reduce wear on the rotor.

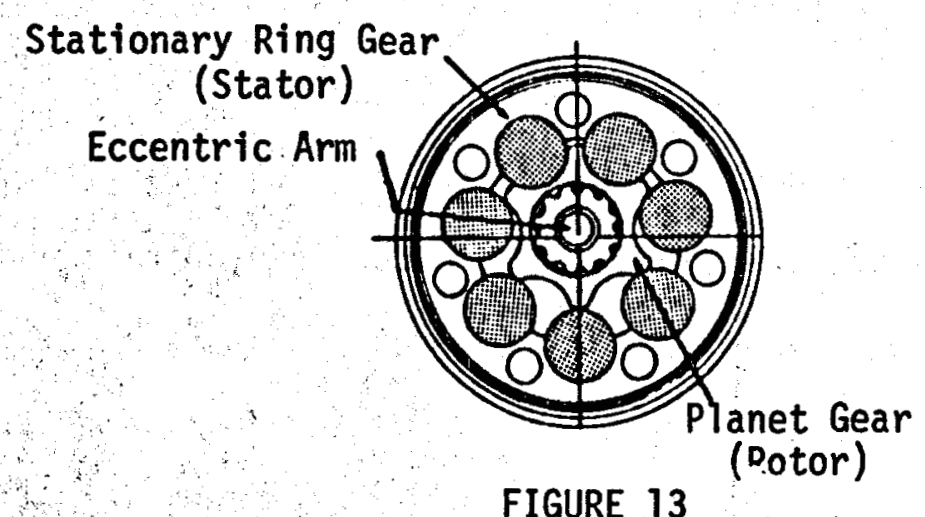

ROLLING INTERNAL GEAR MOTOR

None of the gear motors shown above appear to be good candidates for use as downhole drilling motors because of the abrasive nature of drilling mud. The sand and other abrasives in the mud would quickly wear the contact surfaces and result in excessive leakage. The only gear motor that has found application to date is the Moineau motor which was patented in 1932 (Figure 14).

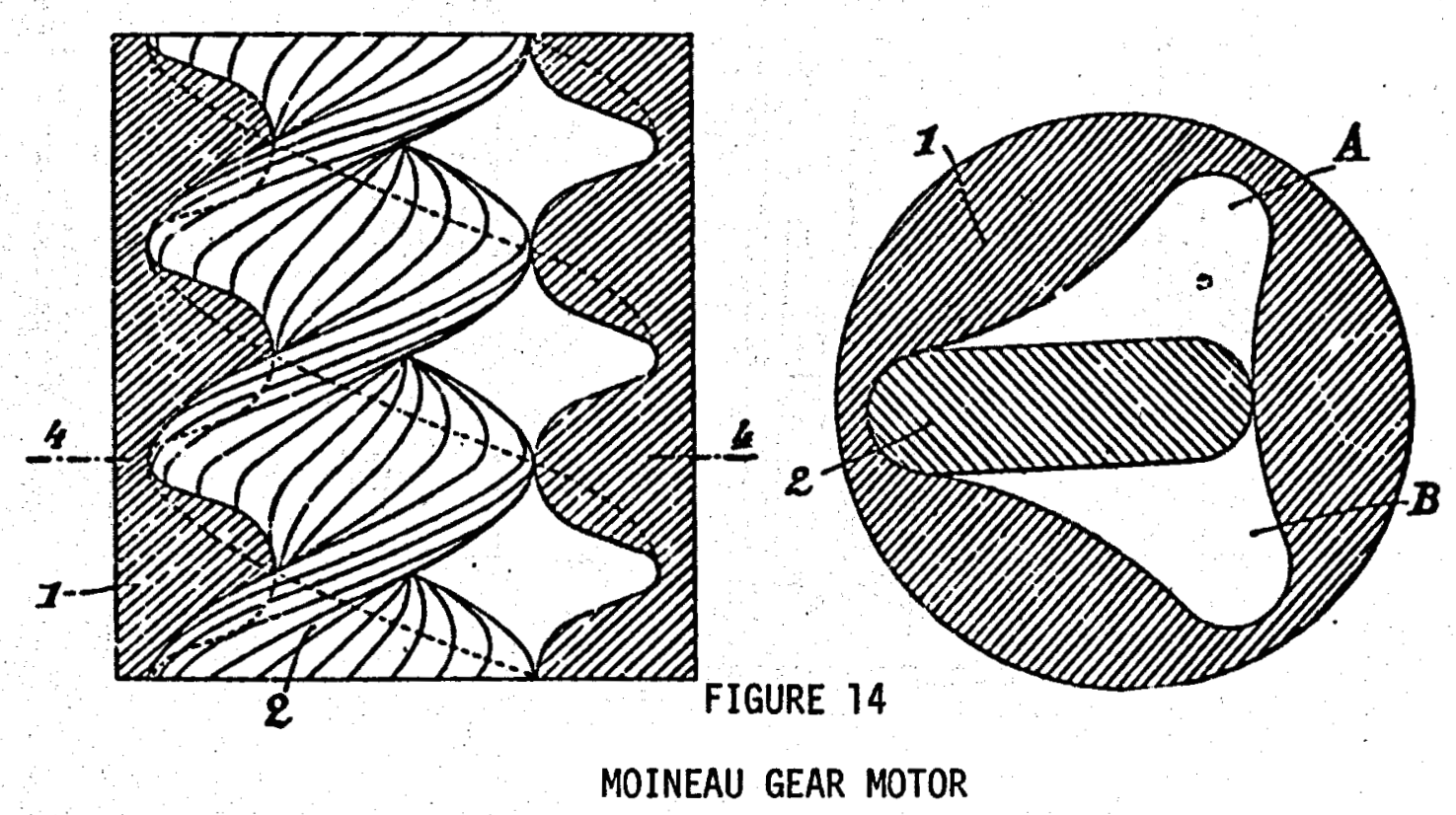


The Moineau motor, which is used in the Dyna-Drill, utilizes an eccentric steel rotor (1) which rotates in a rubber stator (4). The motor consists of two helical gears, the outer gear having one more thread than the inner gear. Fluid trapped between the gears rotates the rotor as fluid is pumped through the motor. Because of the elasticity of the rubber stator, the Dyna-Drill motors can operate hundreds of hours before the wear and leakage become excessive. The elasticity of the stator allows large rock cuttings and other foreign matter to pass through the motor without harming it. These materials could cause serious problems in the other types of gear motors shown.

Figure 15 shows the Moineau principle being used in the Dyna-Drill. A universal joint is used below the motor because of the eccentric motion of the rotor. Ball bearings are used at the bottom of the tool to allow load to be applied to drill bit.

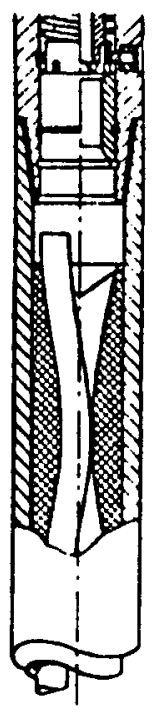

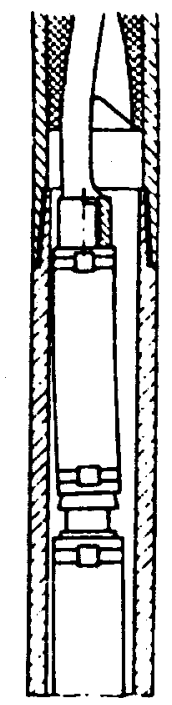

FIGURE 15

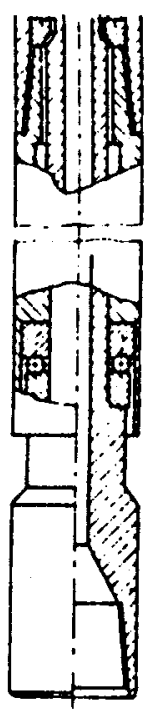

DYNA-DRILL MOINEAU MOTOR 
VANE MOTORS

A candidate for use as a downhole drilling motor is the balanced sliding vane motor shown in Figure 16. Fluid pumped through the motor acts on the sliding vanes causing the rotor to turn.

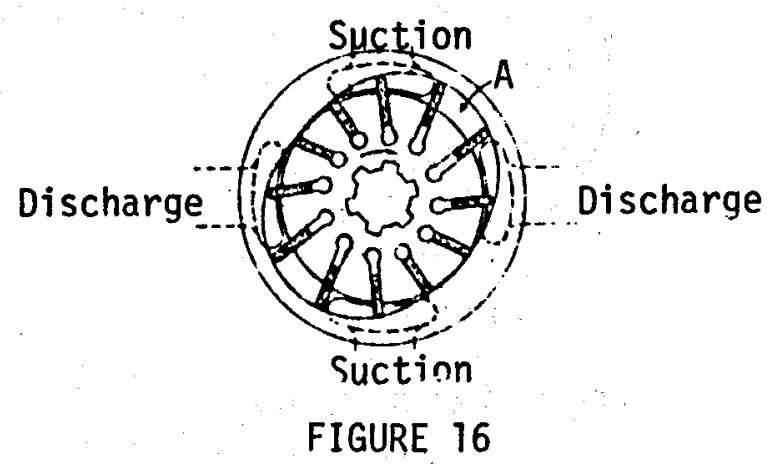

SLIDING VANE MOTOR

Sliding vane motors similar to the one shown in Figure 16 have undergone limited testing in oilwells. These sliding vane motors have potential for both oilwell and geothermal drilling and should be more extensively tested.

The sliding vanes can also be placed in the stator as shown in Figure 17. In this case, the rotor has lobes on it as shown in Figure 17.

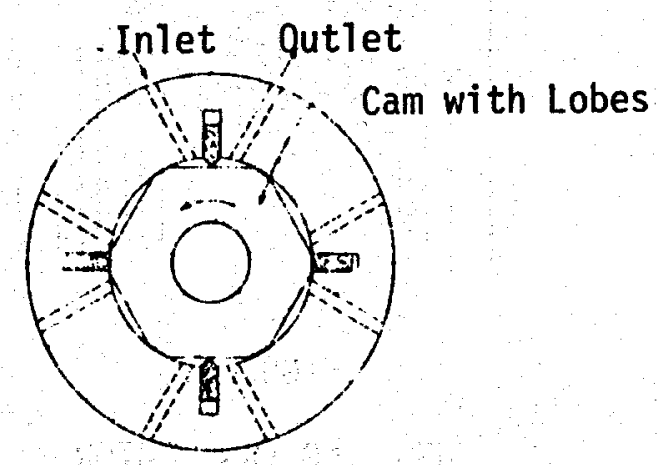

FIGURE 17

LOBE TYPE SLIDING VANE MOTOR 
To reduce wear, the rolling vane motor shown in Figure 18 was developed. Metal contact with the housing is avoided at all times, thereby reducing maintenance problems.

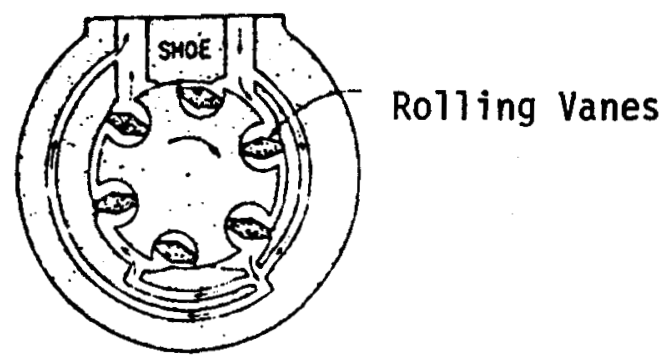

FIGURE 18

ROLLING VANE MOTOR

The flexing vane motor shown in Figure 19 has been tested in oilwells. Although problems, have been encountered with life of the flexing vanes, this motor has potential for both oilwell and geothermal drilling.

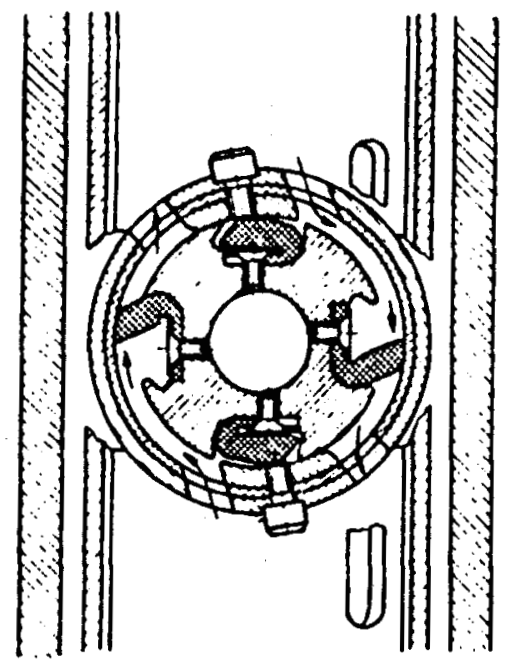

FIGURE 19

FLEXING VANE MOTOR 


\section{ERDA BEARING PACK}

In most downhole drilling motors the thrust bearings are an integral part of the motor as shown in Figure 20.
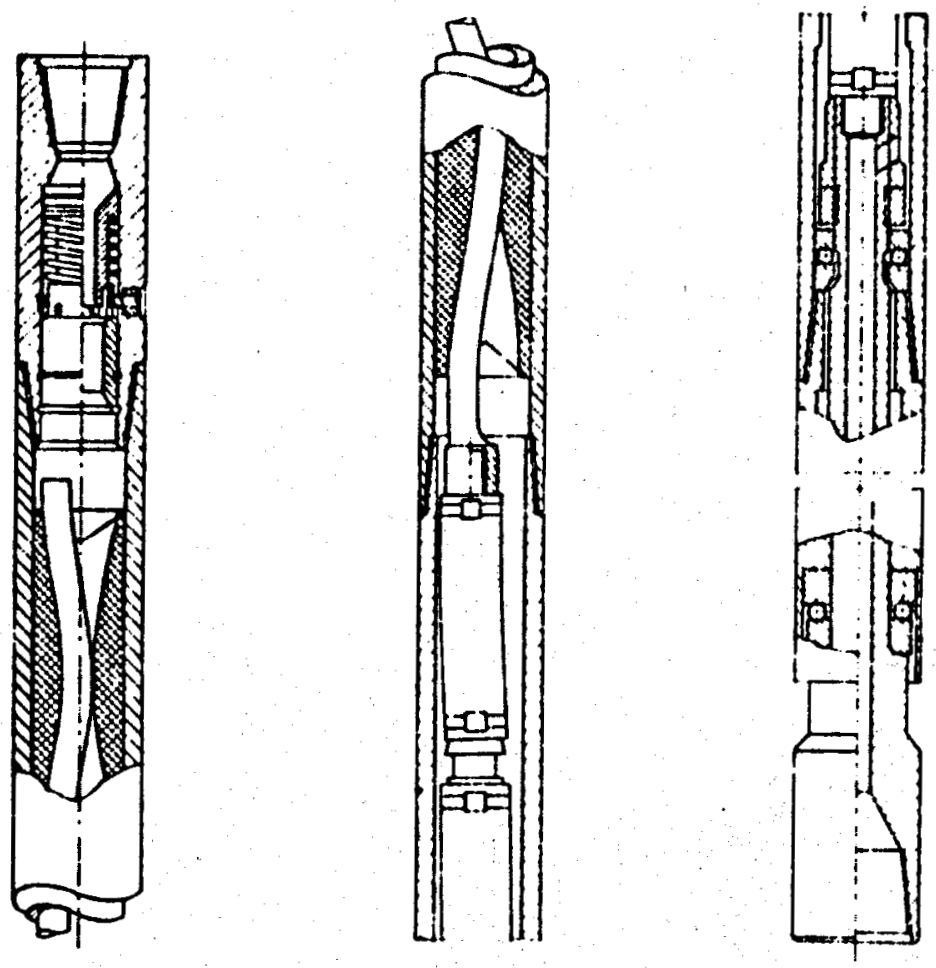

FIGURE 20

DYNA-DRILL MOTOR

This arrangement has serious 1 imitations because the motor sections of these tools normally last five to ten times longer than the thrust bearings and it is necessary to handle the entire tool when repairing the bearings. On offshore rigs it is often necessary to ship the entire tool to a land repair facility, an expensive and time consuming operation. Because of the time delays involved, it is necessary to have several spare motors available on offshore rigs to ensure that there is always at least one motor in operating condition. 
To overcome this problem, a separate bearing package containing all of the thrust and radial bearings is being developed on this ERDA project as shown in Figure 21. This bearing assembly can be easily replaced on the motor when the bearings and/or seals fail, thus reducing the inventories and costs involved

FIGURE 21

NEW ERDA BEARING PACK 
The ERDA bearing pack consists of eight main components.

- Bearing Housing (7)

- Bearing Shaft (1)

- Lubricant Reservoir (41)

- Floating Piston (23)

- Thrust Bearings (18 and $\left.18^{\prime}\right)$

- Thrust Ring (19)

- Radial Bearings (12 and 21)

- Rotary Seal (4)

HOUSING AND DRIVE SHAFT

The housing and drive shaft of the ERDA bearing pack will be made of either AISI 4140 or AISI 4340 alloy steel heat treated to $30-35 R_{c}$. In normal operation, the bit torque is transmitted through the bearing shaft to the turbine rotor. The bearing housing is subjected only to the torque produced by bearing friction and by borehole wall friction if the drillpipe is being rotated. The upper part of the bearing housing is subjected to the loads on the thrust bearings.

The bearing shaft is attached to the turbine rotor by hexagonal or elliptical spline couplings containing wire mesh elements which transmit the torque and absorb torsional shocks.

\section{LUBRICATION RESERVOIR}

Most downhole motors allow mud to continually leak through the bearings. Drilling mud is very abrasive, resulting in failure of the thrust bearings in 20 to 40 hours in most cases. 


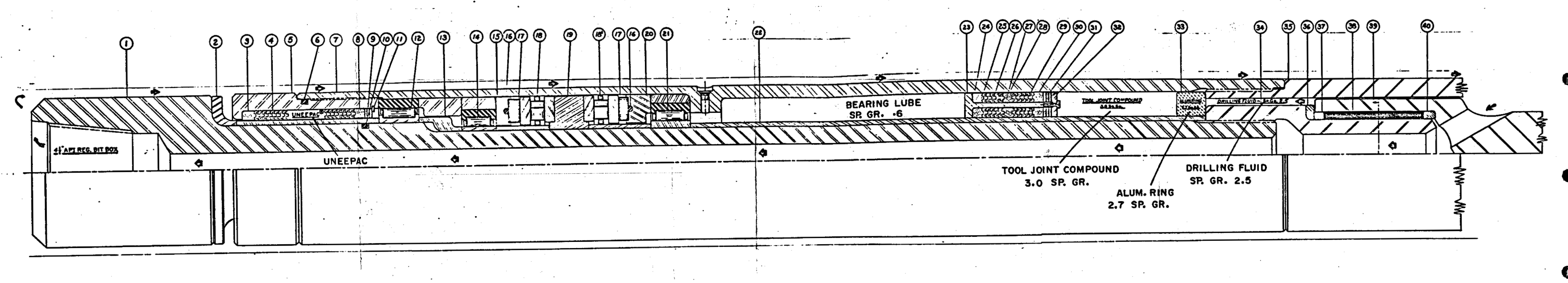


The bearings in the new ERDA bearing assembly operate in oil or grease sealed in a lubrication reservoir. Various types of petroleum derivative and synthetic lubricants are being tested under simulated bottomhole conditions to find the best lubricant for this application.

\section{FLOATING PISTON}

A floating piston is used to pressurize lubricant in the lubrication reservoir. Mud pressure inside of the drillpipe acts on top of the floating piston, pressurizing the lubricant. The piston seals, which are not subjected to pressure differential, are supported in an aluminum housing to minimize inertia. The floating piston does not rotate, consequently the shaft rotates inside of the sear. These seals are placed in opposing directions to relieve the pressure between the seals and to prevent the high ambient downhole pressure from extruding the seals and locking the floating piston.

A grease of higher specific gravity than the drilling fluid will be used above the floating piston. An aluminum separator ring of lower specific gravity than the grease and higher specific gravity than the drilling fluid will be used above this heavy grease. The purpose of the separator ring is to restrict agitation and prevent emulsification of the grease-mud interface.

\section{THRUST RING}

A thrust ring attached to the drive shaft by sleeves applies 
thrust to the thrust bearings. When mud is pumped through the motor, the pressure drop across the turbine produces a hydraulic downthrust on the rotor. When the motor is operated off bottom, the hydraulic downthrust loads the lower thrust bearings. At high bit weights, the bit load exceeds the hydraulic downthrust, resulting in upward directed loading of the upper thrust bearing.

\section{THRUST BEARINGS}

Existing downhole motors utilize either rubber friction thrust bearings or ball thrust bearings. Problems arise with wear of the rubber bearings and with spalling and wear of the ball races and ball bearings.

El imination of a sleeve at the outer edges of the thrust bearing allows the use of commercially available roller thrust bearings in the ERDA bearing assembly. These roller bearings have an order of magnitude higher thrust capabilities than the ball bearings or the rubber friction bearings used in existing motors.

\section{RADIAL BEARINGS}

In general, radial bearings are much less of a problem in downhole motors than thrust bearings because of the lower loads and because space constraints are less of a problem with the radial bearings. The radial bearings increase the motor stiffness, prevent excessive bending of the tool during directional drilling and centralize the shaft to reduce seal wear. Three radial roller bearings will be used in the ERDA bearing pack. 
ROTARY SEAL

A positive rotary seal which allows essentially no leakage will be used to seal the lubricant in the reservoir around the bearings. The rotary seal is subjected to the pressure drop across the bit. Existing motors can operate effectively with maximum bit pressure drops of only 200 to $400 \mathrm{psi}$. This is not sufficient for good bottomhole cleaning, resulting in reduced drilling rate. The new ERDA seals are designed for operation of drill bits at pressure drops of 500 to 1,000 psi. Any minor lubricant leakage past these seals will be made up by downward movement of the floating piston.

At least six different types of rotary seals will be tested during this program, including Chevron, Uneepac, and novel seals. Attempts are being made to develop a redundant rotary seal which is activated when the primary rotary seal leaks. This should greatly increase the seal life and should allow replacing the seals during trips to change the bits. 


\section{CANDIDATE SEALS}

Several promising seal designs and applications have been selected for the initial seal tests to be performed in the seal $t$ st vessel. Marine, Labyrinth and Flow Restrictor rotary seals have been ruled out for use in the ERDA bearing assembly because they leak continuously and are not positive seals.

Face seals have been ruled out because of the poor performance shown by these seals in numerous drilling motor applications. "Pumping" the faces open, and allowing abrasive solids to come between the faces thereby scoring the lapped surfaces is the most serious problems. Face seals will be reconsidered if packing seals do not operate effectively.

Packing and Radial Lip type seals will be tested initially for this program. Meetings have been held with representatives of over 20 different seal companies and the following seals have been selected as candidates for use in the ERDA drilling motor bearing assembly:

1. Chevron Packing (V) - Bayou City Rubber, Inc.

2. Chevron Packing (V) - Custom Rubber Products

3. Chevron Packing (V) - Engineering Enterprises

4. Uneepac Packing (W) - Johns-Manville

5. Radial Lip - Utex Industries, Inc. 
The Chevron and Uneepac Packing seals operate in a similar manner and the primary difference between them is in the compounds used in making them. The Radial Lip seals differ from packing seals in that only one seal is loaded at a time whereas the Cherron and Uneepac seals are all loaded simultaneously.

The Bayou City Rubber Company Chevron packing seals shown in Figure 22 are composed of a Dupont EPDM base material.

Bayou City Rubber representatives state that by careful compounding of the EPDM base material, these seals should operate effectively at temperatures of 500 to $550^{\circ} \mathrm{F}$.

The proposed compound has the following physical properties:

$\begin{array}{ll}\text { Tensile Strength } & -2100 \text { psi } \\ \text { Elongation } & -700 \text { percent } \\ \text { Hardness } & -59 \text { Shore A } \\ \text { Comp. Str. }\left(22 \mathrm{hrs} . \mathrm{C} 2.57^{\circ} \mathrm{F}\right) & -22 \text { percent }\end{array}$

These Chevron "V" rings will be molded in a curved plane to eliminate line contact with the shaft. Plans are being made to make a single cavity mold to produce this packing. 


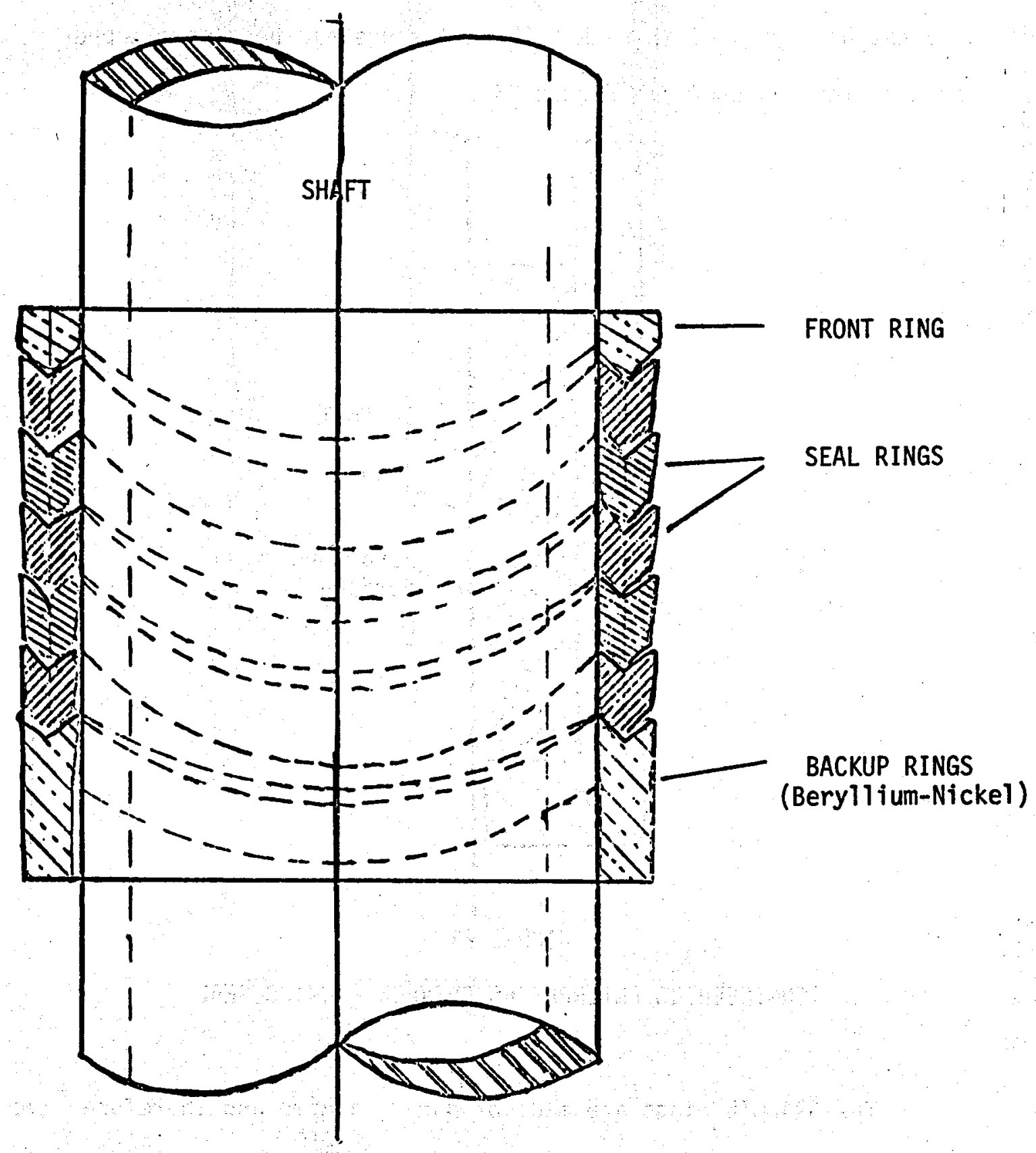

FIGURE 22

BAYOU CITY RUBBER CHEVRON PACKING SEAL 
The Engineering Enterprises Packing seal assembly consists of alternating layers of thin GRAFOIL seal rings and beryllium copper back-up rings as shown in Figure 23.

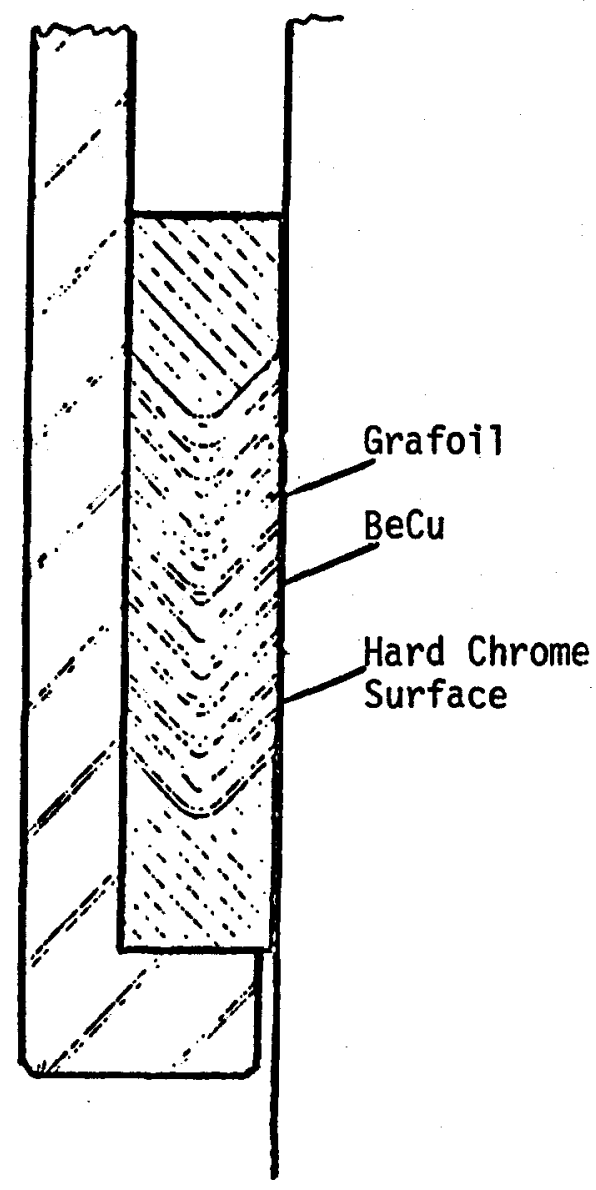

FIGURE 23

ENGINEERING ENTERPRISES CHEVRON PACKING SEAL

The GRAFOIL rings are made of pure graphite and therefore have good lubricity and good thermal conductivity. The high thermal conductivity is important in dissipating the heat generated at the sliding seal surface since heat buildup is the major cause of rotary seal failures. These seals are currently being tested in the Engineering Enterprises turbo-drill and are a leading candidate for use in the ERDA bearing assembly. 
The Johns-Manville "Uneepac" seal assembly, shown in Figure 24 is also a candidate for use in the ERDA bearing assembly. These seal rings were successfully used in the Exxon 15,000 psi swivel.
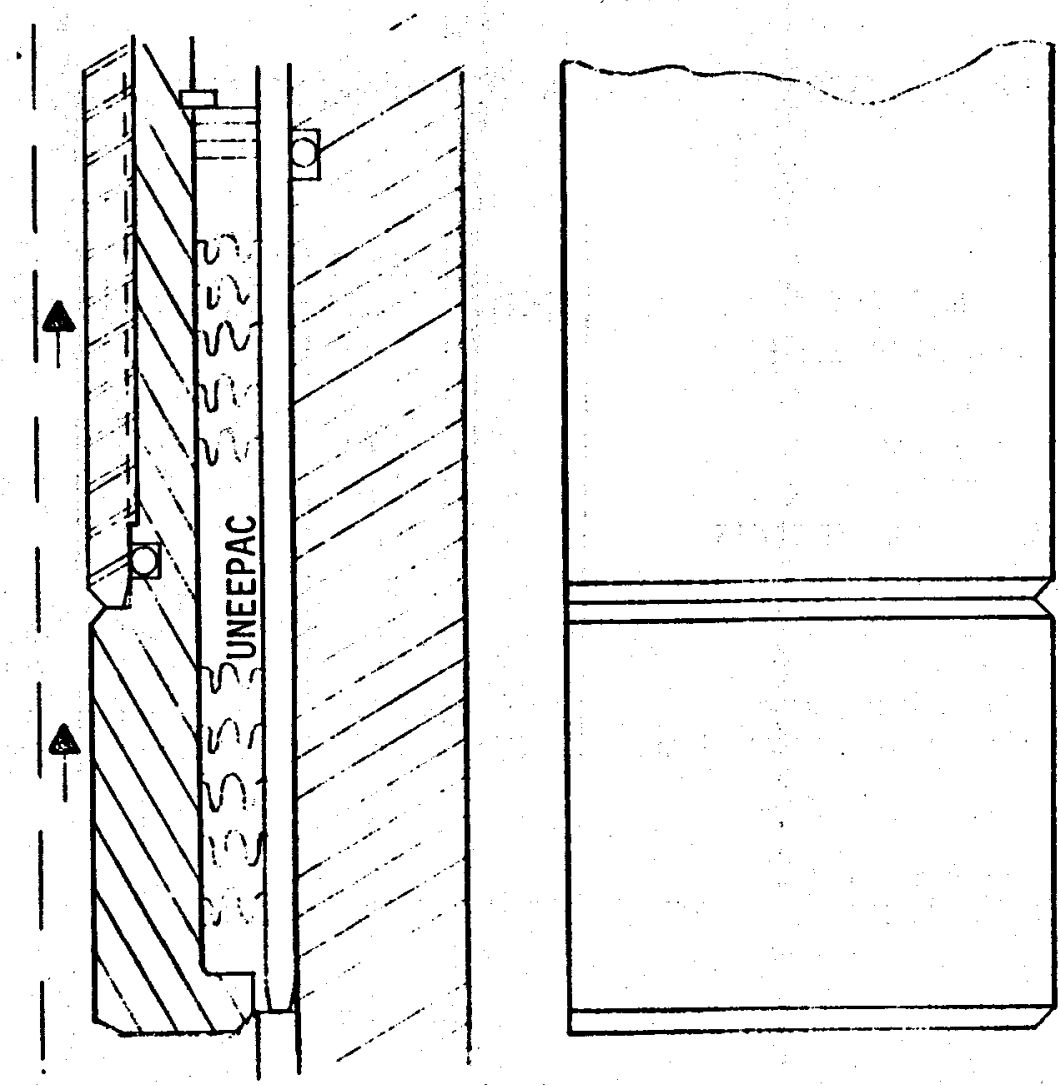

FIGURE 24

JOHNS-MANVILLE UNEEPAC SEAL

The Uneepac rings come in conventional and deep base designs.
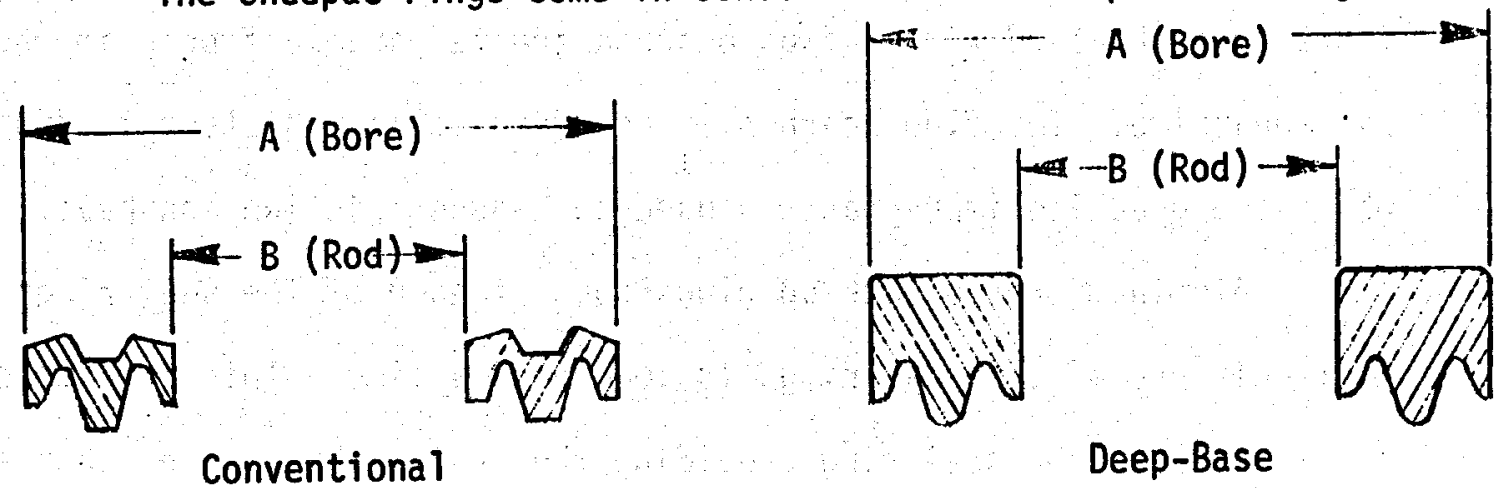

FIGURE 25

JOHNS-MANVILLE "UNEEPAC" PACKING SEALS 
These Uneepac seal rings come in several different compounds that operate at temperatures up to $500^{\circ} \mathrm{F}$ as shown in Table I. The style 470 VITON rings will be used in the initial tests.

\section{TABLE I}

\section{MATERIALS USED IN JOHNS-MANVILLE UNEEPAC SEALS}

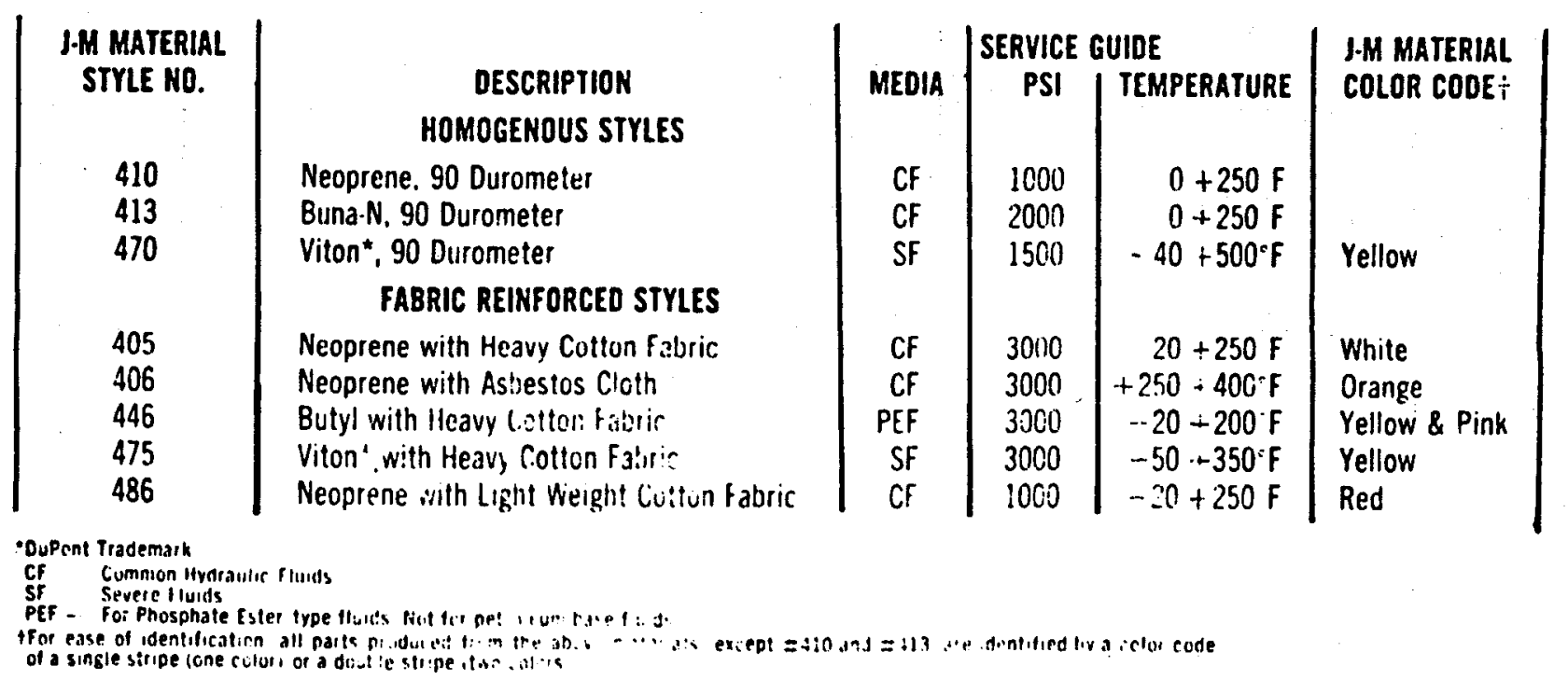

Utex Industries has two seal designs that are candidates for use in downhole drilling motors. The conventional Radial Lip seal arrangement shown in Figure 26 utilizes Style RD-136 seal rings composed of a ceramic fibre core sheathed with a fluorocarbon treated aramid fabric impregnated with graphite. The fluorocarbon treated fabric is resistent to $450^{\circ} \mathrm{F}$ while the graphite impregnant is used to reduce friction and heat.

Aluminum bronze back-up rings support each of the seal rings so that only one of the seal rings is loaded at a time. This arrangement limits wear to the seal ring providing the seal. This is in contrast 
to Chevron and Uneepac seals (Figures 22 to 24 ) where each seal ring loads the seal ring beneath it and they all wear simultaneously. This is a major advantage of the Utex seals over the packing seals.

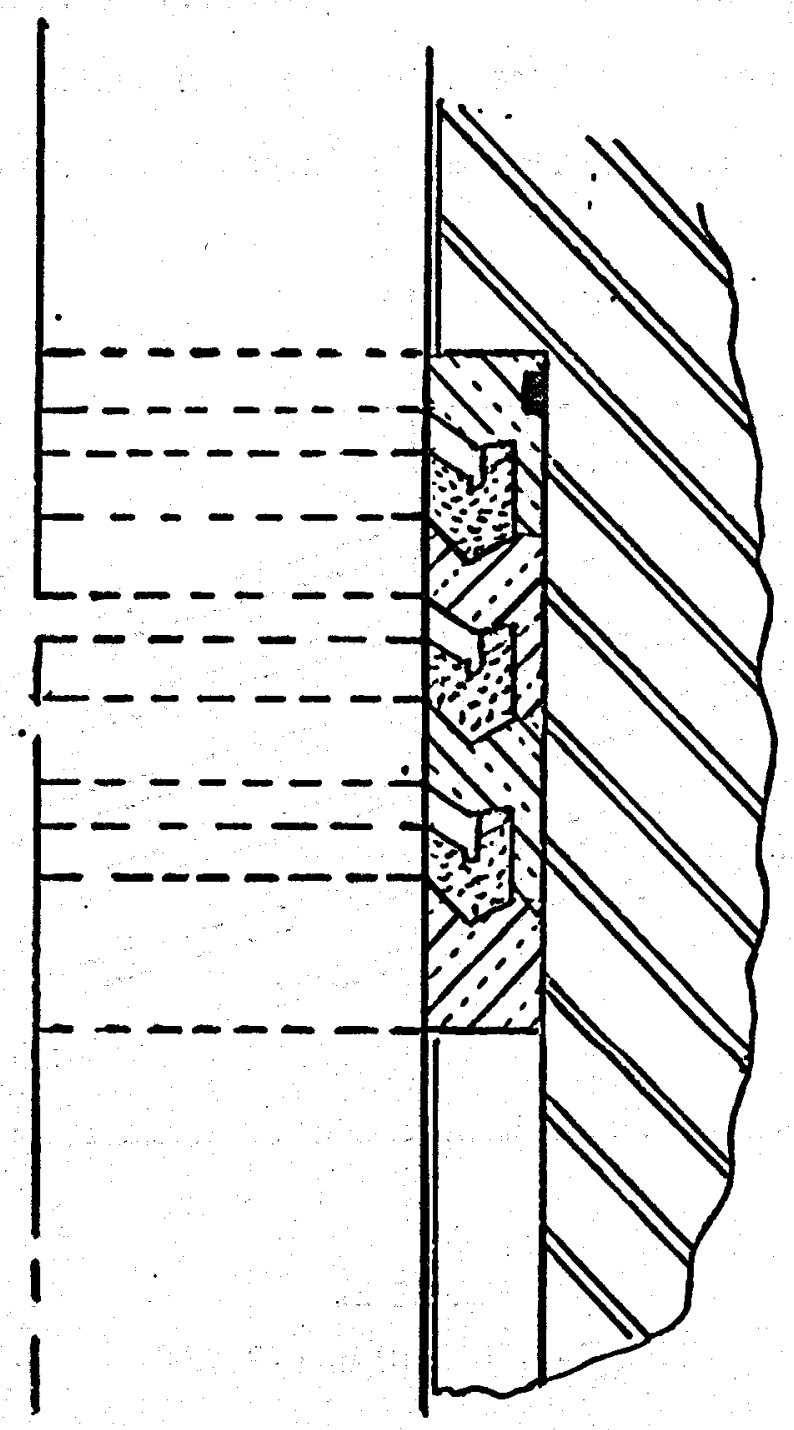

FIGURE 26

UTEX CONVENTIONAL RADIAL LIP SEAL 
One problem with rotary seals is that sealing occurs along a line around the rotating shaft resulting in high heat generation and high temperatures at this interface. The high temperature often degrades the lubricant and causes high friction at the line contact which leads to rapid failure of the seal. Utex has proposed the unconventional "canted" seal, shown in Figure 27 which overcomes this problem. As the shaft rotates, the shaft surface is continually lubricated since the seal comes into contact with each point on the shaft surface only twice every revolution. This should result in cooler operation and longer Tife.

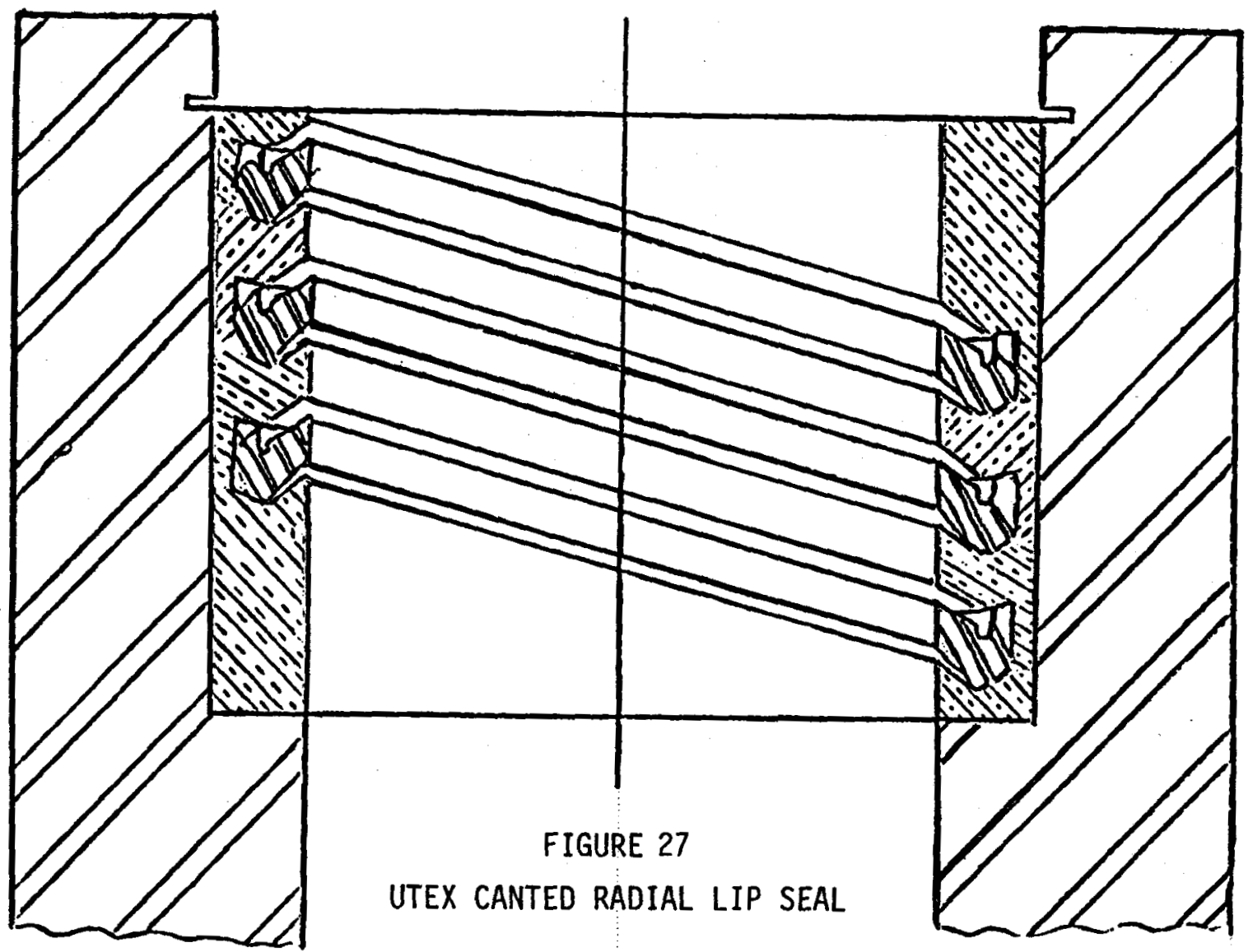

When the seals in a downhole motor fail, it is necessary to make a "round trip" in order to replace the seals in the motor. This is expensive since it may take up to 20 hours to make a round trip in a deep well where rig costs are on the order of $\$ 5,000$ per day. It would therefore be advantageous to have spare or redundant rotary seals which are 
not subjected to pressure until the primary seals fail. The redundant seals would activate automatically or by a command from the surface, (e.g., go-devil or pressure pulse). This would reduce the time to replace the seal from 10 to 20 hours to a few minutes.

Dupont has developed a new purfluoroelastomer trademarked KALREZ which has better high temperature properties than TEFLON. This material is a hybrid of TEFLON (PTFE) and VITON (Fluoroelastomer) and as such combines the high temperature properties of TEFLON with the resilience of VITON. This perfluoroelastomer has much better high temperature properties than TEFLON-coated VITON as shown in Figure 28. KALREZ is a candidate material for use in downhole motor seals and will be tested if the more readily available seals do not perform satisfactorily.

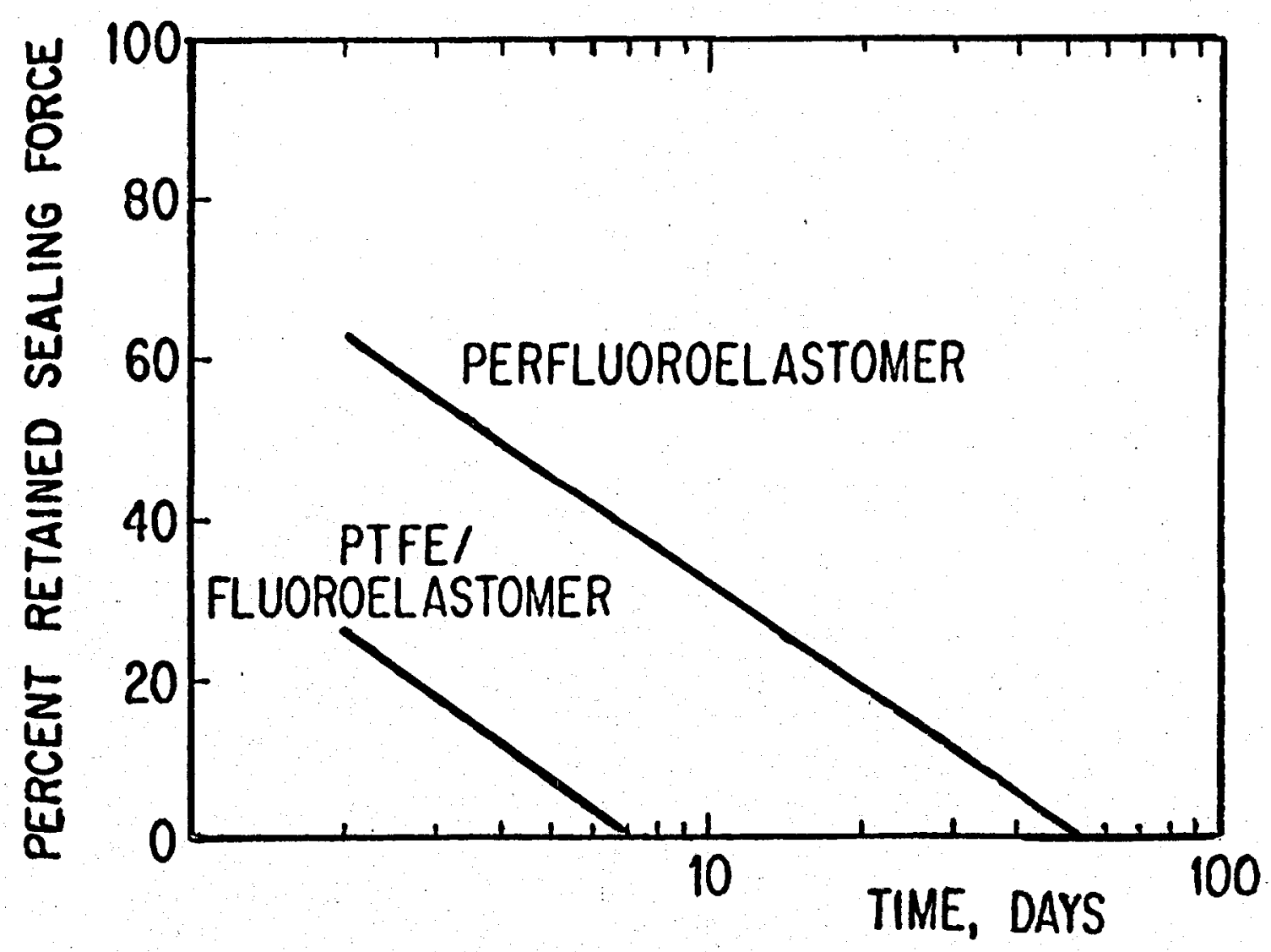

FIGURE 28

COMPARISON OF SEAL RETENTION FORCE AT $500^{\circ} \mathrm{F}$ 


\section{BEARING APPLICATION}

As stated earlier, short bearing and seal life are two of the major shortcomings of current downhole motors. To improve bearing life, an attempt was made to select higher capacity, longer life bearings that could be incorporated into an improved downhole motor design.

The bearings selected for use in the ERDA bearing package are larger than any used in commercial $73 / 4$ inch drilling motors (4 inch I.D. by 7 inch 0.D.) as shown in Table II below. The larger size allows the use of roller bearings which have much higher thrust load capabilities than ball bearings.

TABLE II

Comparison of Motor Thrust Bearings

\begin{tabular}{|c|cc|cc|c|}
\hline Motor & $\begin{array}{c}\text { Bearing } \\
\text { Type }\end{array}$ & $\begin{array}{c}\text { Bearing } \\
\text { Number }\end{array}$ & $\begin{array}{c}\text { Inner } \\
\text { Diameter } \\
\text { (in) }\end{array}$ & $\begin{array}{c}\text { Outer } \\
\text { Diameter } \\
\text { (in) }\end{array}$ & $\begin{array}{c}\text { Basic } \\
\text { Load Rate } \\
\text { (pounds) }\end{array}$ \\
\cline { 2 - 3 } & Ball & 920 & 3.94 & 5.91 & 27,600 \\
ERDA* & Ball & 725 & 4.92 & 6.89 & 33,100 \\
ERDA & Roller & RTH-734 & 4.00 & 7.00 & 122,000 \\
\hline
\end{tabular}

* Similar to $73 / 4$ inch Dyna-Drill Bearings 
The Basic Load Rating of a bearing is defined as the bearing load at which 10 percent of the bearings will fail after 1 million revolutions. Table II shows that the load factor of the roller bearing is 122,000 pounds compared to 33,100 pounds for the largest ball bearing that can be used in the ERDA assembly and 27,600 pounds for the bearing used in the commercial turbodrill.

The life of a lubricated bearing can be estimated as follows:

$$
\begin{aligned}
& L_{10}=\frac{16667}{N}\left(\frac{C}{P}\right)^{3} \\
& L_{10}=\frac{16667}{N}\left(\frac{C}{P}\right)^{3.33}
\end{aligned}
$$

NOTE: These standard bearing life calculations were taken from the Torrington Company's Torrington Bearings Catalog \#467.

where

$$
\begin{aligned}
& \mathrm{L}_{10}=\text { Bearing Life (hours) } \\
& \mathrm{C}=\text { Basic Load Rating (1bs) } \\
& P \quad=\text { Bearing Load (1bs) } \\
& N=\text { Rotary Speed (RPM) }
\end{aligned}
$$

For a motor rotating at 500 RPM with 30,000 pounds bearing load, the life of the bearings in Table II will equal:

$$
\begin{aligned}
& \text { Turbodrill (ba11) }=\frac{16667}{500}\left(\frac{27,600}{30,000}\right)^{3}=26.0 \text { hours } \\
& \text { ERDA (bal1 }=\frac{16667}{500}\left(\frac{33,100}{30,000}\right)^{3}=44.8 \text { hours } \\
& \text { ERDA (roller) } \quad=\frac{16667}{500}\left(\frac{122,000}{30,000}\right)^{3.33}=3580 \text { hours }
\end{aligned}
$$


This calculation shows that the predicted life of the roller bearing is 3580 hours compared to 44.8 and 26 hours for the ball bearings. As a note, this is an idealized calculation assuming constant load on the bearing. These are calculations used in the bearing industry, however, to get an approximation of life of bearings for "normal" industry application. For the downhole drilling motors, the 30,000 pounds bearing load may be a desired quantity; but in reality, the bearings are forced to operate at possibly as little as 2,000 pounds "average load" with load excursions which may be as great as 50,000 pounds. (This is a rough estimate, since no significant data really exists.) Nevertheless, the estimated 3,580 hours is an order of magnitude increase in "predicted life" which shows that there is potential for major improvements with the bearing assemblies being developed. 


\section{SEAL TESTER DESIGN DETAILS}

In order to evaluate the performance of new and conventional seals, a seal test facility was necessary. Before this facility could be built, however, background information had to be obtained to determine the downhole conditions present in the geothermal environment. The following parameters were considered in the design of the seal test facility: absolute pressures and pressure difference across the test seals; pressure fluctuations; temperature; seal size; relative axial displacements between the seal and the rotating shaft; radial eccentricity of the rotating shaft; dynamics; and rotary speed.

Actual data from downhole geothermal operations is extremely limited, so calculations and some assumptions had to be made as to the conditions faced by the seal in a downhole motor. Moreover, since conditions vary widely depending on the location, depth, and rock type of a particular we11, the test apparatus was designed to be versatile enough to allow the simulation of different environments.

Another important parameter for the seals tests is a definition of seal "failure". The actual limitations imposed by the downhole motor must be considered in failure analysis. For example, a moderate amount of leakage is normal and necessary for the proper operation of some seals. However, if this leakage rate drains the total oil reservoir in the drilling motor in short order, the seal is unsatisfactory even though 
it may be operating as it was designed to. Hence, "failure" must be a leading design related reason for rejecting seals as possible choices for downhole tools.

After careful consideration of the background information, the following general limits were chosen for the design of the seal test facility:

(1) Pressures to 5,000 psi;

(2) Pressure differentials across the seal up to 5,000 psi;

(3) Pressure pulsations up to 500 psi (in addition to steady state pressures);

(4) Temperatures from $32^{\circ}$ to $600^{\circ} \mathrm{F}$;

(5) RPM from 100 to 1700 RPM;

(6) Radial shaft eccentricities of 0 to .010 inches;

(7) Axial shaft eccentricities of 0 to .020 inches;

(8) Pressure medium consisting of various lubricants, water, or drilling mud mixed with cuttings, sand, or other abrasives.

Seal test conditions, including a discussion of independent and dependent variable parameters, is discussed in detail in the Semi-Annual Report (TR76-59) and more detailed information can be found there.

Many concepts were considered for the seal test apparatus. The final design is shown in Figure 29. This design uses a pressure balanced system, the high pressure area is located between the two test seals with equal low pressure areas on the opposite end of each seal balancing the forces on the rotating shaft. If one seal should fail abruptly, an unbalanced force is created, forcing the rotating shaft in the direction of the failed seal. A thrust bearing is provided on the rotating shaft to control axial movement and this bearing should be sufficient for any unforeseen seal failures that occur. Other advantages 


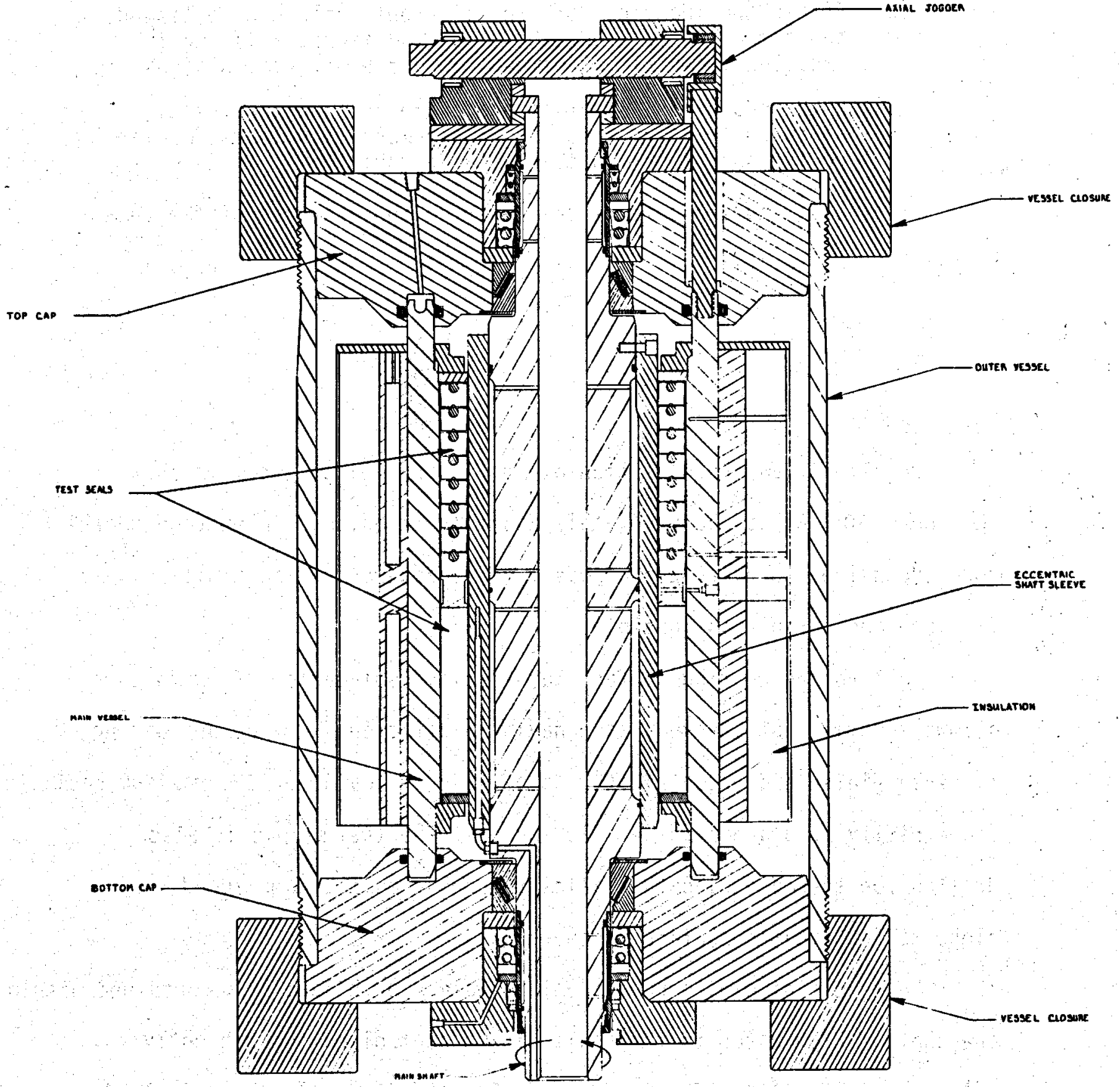

FIGURE 29

SCHEMATIC OF THE SEAL TEST VESSEL 
of this seal test design facility are:

(1) High pressure mud and abrasives can be introduced between the test seals with no contact with the bearings or the outer seals;

(2) Either two identical or two different seals can be tested at the same time or under the same conditions, allowing for excellent comparison between two different seal designs;

(3) Both ends of the rotating shaft are outside the vessel, allowing greater access for instrumentation leads, cooling ports, and other input into the vessel.

The following are some of the major design features of the test vessel.

\section{ROTARY SHAFT}

A simplified cross section of the rotary shaft system is shown in Figure 30 . As can be seen, this assembly is quite complex (and therefore expensive) so every effort was made to assure this part will be as flexible and durable as possible.

All rotary wearing surfaces are easily replacable. This feature allows several test sleeves, each having a different surface or coating, machined finish and eccentricity, to be made in advance. The maximum radial eccentricity is planned to be .010 inches. The test sleeve is also drilled for thermocouples that allow temperatures to be measured very close to the dynamic surface of the seal.

A tube manifold to route cooling water to the seals is contained within the shaft. Flow rates to the seals can be controlled independently to allow greater cooling of the vessel seals. Additionally, heated fluid can be supplied to the test seals to further simulate downhole conditions. 


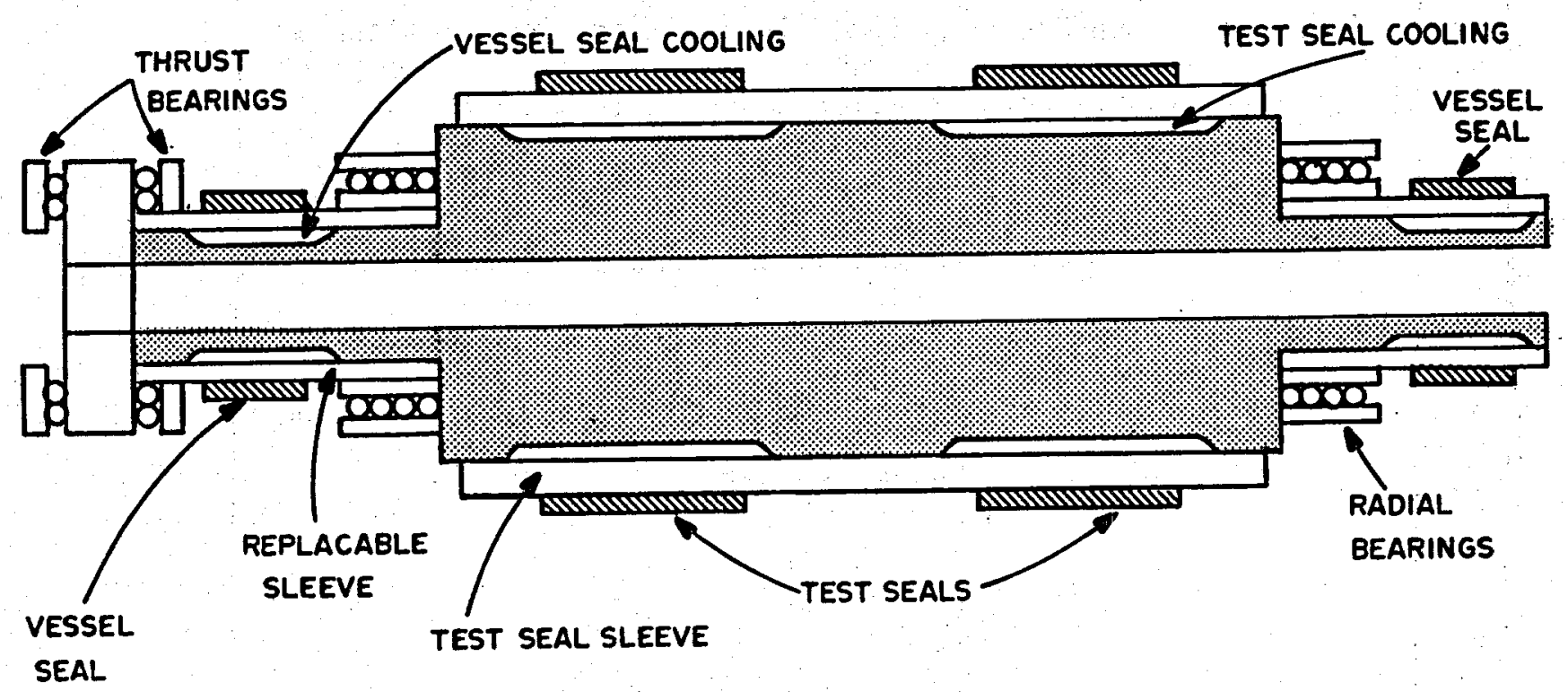

FIGURE 30

SIMPLIFIED CROSS-SECTION OF THE ROTARY SHAFT

\section{SEAL CARRIER}

The seal carrier is another important component which was designed as simply as possible since several carriers are needed to hold seals of different sizes. To allow for simulated axial run-out of the shaft, the seal carrier can be moved axially with respect to the shaft. The seals are firmly attached to the seal carrier, hence the sliding action will take place between the seal and the dynamically rotating shaft sleeve. The seal carrier also serves as the pressure vessel. The outer vessel is used as an alignment fixture and reacts the axial loads, but the seal carrier supports all radial pressure loads. 
VESSEL SEAL HOUSINGS

The vessel seal housings were designed to use the most reliable seals available at the present time. In addition, the diameter of the vessel seals is significantly smaller than the test seals, which correspondingly reduces the surface speed. In addition, these seals will be cooled and are isolated from the heated portion of the vessel and will be subjected to only very small radial and axial eccentricities. The stacked seal feature allows one set of seals to be completely worn out and still allow testing to continue using the back-up seals.

\section{HEATER CARRIER}

The total heater capacity for the vessel is 30 heaters, each rated at $1 \mathrm{KW}$, divided evenly in two banks around the test seals. The heater carrier is designed such that there is a close fit with the seal carrier on the inside diameter for good heat transfer. A layer of castable ceramic surrounds the heater carrier on the outside diameter to prevent heat - loss. This castable ceramic is in turn covered with a sheet metal liner to preserve and protect it from impact damage.

\section{WATER SWIVEL}

A separate swivel shaft is connected through a spline to the main shaft below the test vessel. This swivel shaft is designed to allow the passage of cooling water to the test seals through the rotary shaft, as well as to the vessel seals. All flows can be controlled and monitored independently to determine the heat loss through the cooling water and also to identify problems in the vessel seal if excessive heating of the cooling water should occur. 


\section{TORQUE CELL}

The torque cell is also connected to the main shaft through a spline and is designed to measure the torque required to turn the shaft against the test seals as well as the vessel seals. Since an increase in torque is an important indication in the failure process of a seal, proper operation of this transducer is critical to the accurate evaluation of a new seal design.

\section{SLIP RING}

Ali electronic instrumentation readings made on the rotary shaft will have to be translated to stationary pick-ups through a slip ring to allow for recording. Instrumentation in the shaft includes the torque cell and the rotary thermocouples.

An overall layout of the complete test system can be seen in Figure 31. Extensive electronic equipment is required to amplify and record the signals produced by the transducers, control the temperatures and pressures, and monitor the system for possible problems that require attention. In addition, work spaces for the machine operaters are provided along with the necessary tools and hoists to allow seals to be changed easily. 


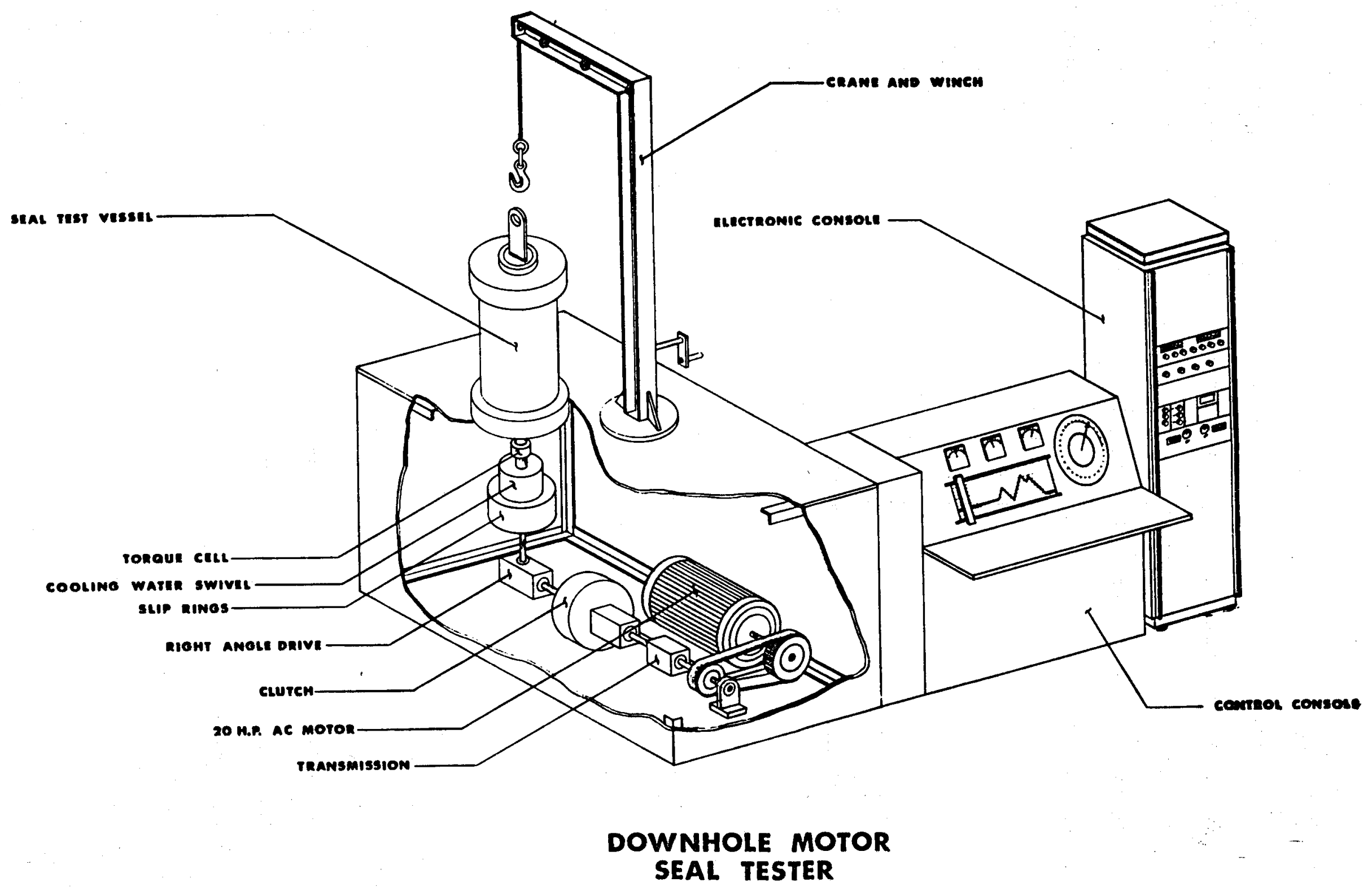

FIGURE 31 
SELECTED CONDITIONS FOR THE INITIAL SEAL TESTS

As stated, the seal test facility was designed to allow simulation of a wide range of downhole drilling conditions. For the initial tests, however, it was necessary to choose reasonable values for temperatures, pressures, and other parameters in order to establish a base for comparison. The following conditions were selected as a reasonably conservative set to which later and more radical tests could be compared.

PRESSURES - The high and low pressures were chosen as 3,000 psi and 1,500 psi respectively. The most important aspect of the pressures selected is not the absolute pressure levels as much as the pressure difference. across the test seals. A pressure difference of 1,500 psi under actual drilling conditions would allow the high flow rates necessary to properly clean the hole bottom.

TEMPERATURE - The initial test temperature selected is $250^{\circ} \mathrm{F}$. Obvious $7 y$, seals that are proven reliable for higher temperatures would be more desirable, however, data available at this time suggests that there is a significant need for a reliable seal even to $250^{\circ} \mathrm{F}$. In the interest of obtaining considerable base line data, this temperature level was selected. 
To best simulate an actual seal temperature history, a higher temperature "soak" period is being considered even for the initial tests. This soak would consist of heating the seal statically to temperatures high enough to simulate actual formation temperatures. This period would correspond to a typical trip time during which a motor is exposed to the formation temperatures without the benefit of cooling from the drilling fluid. After this static soak period, the temperature level would be lowered to $250^{\circ}$ and rotation would begin. It is expected that the seal will react much differently to static high temperatures as opposed to rotation (with the associated friction heating and dynamic stresses) which is a much more severe test.

ROTATIONAL SPEED - An 800 RPM rotary speed was selected as the test speed for the initial tests. Although, as stated earlier, rotational speeds as low as 50 RPM are desirable for some types of drilling, realistic evaluation of past attempts at downhole motor speed reduction systems suggest 800 RPM as a reasonable test speed. In addition, seal life should naturally increase as rotational speed decreases. Any seal developed for high speed use will be readily adaptable for lower speeds. 
TEST FLUIDS - Commercial E.P. 90W gear lubricant was chosen as the test fluid for both the low and high pressure chambers. In actual drilling, the low pressure fluid is drilling mud. Failure occurs in an actual motor when the pressurized lubricant that is sealed into the bearings leaks out and allows drilling mud to reach the high pressure side of the motor seals. Since leakage of lubricant will be monitored during the tests, it will become apparent if a seal is unsuitable due to excessive controlled leakage as well as seal failure. Tests using drilling mud as the high pressure fluid can be performed in the future if initial tests on seals warrant.

DYNAMIC SURFACES - The surface of the rotating sleeve in contact with the test seals is an important parameter affecting seal life. Some composite surface treatments wear in such a way that the softer matrix material wears away leaving the harder materials protruding much like fine sandpaper. To eliminate inconsistencies, hard chrome plating, $\left(R_{c} 72-75\right)$, ground to 8-16 $\mu$ inches, was chosen as the initial test surface. This surface is identical to that used in present downhole motors.

RUNOUT SIMULATION - At the present time, the axial as well as the radial runout of the rotating shaft in a downhole motor is not well defined. Although it is obvious that the seals do experience loadings caused by runout, axial jogging and radial eccentricity will be omitted for the initial test series. As more seal data is collected for a base of comparison, simulation of this movement will be incorporated into the tests. This provision has already been included in the seal tester. 


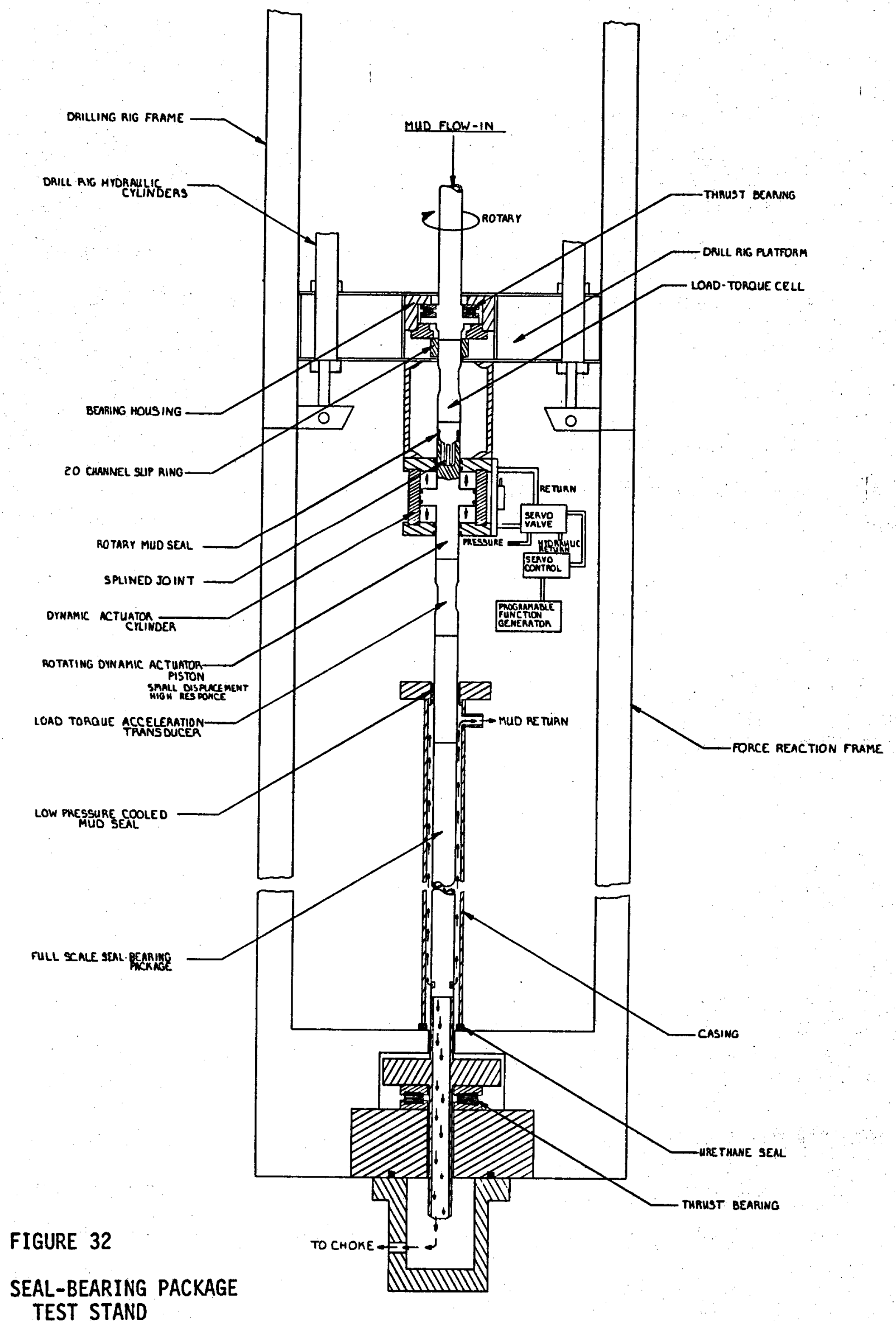




\section{SEAL-BEARING PACKAGE TEST STAND DESIGN}

A preliminary design of the fixture necessary to adapt the sealbearing package for full-scale laboratory tests in the Drilling Research Laboratory has been completed. As can be seen in Figure 32 this test stand will include a thrust bearing for carrying the thrust load to be transmitted through the seal-bearing sub, and a choke assembly to allow for an effective pressure drop across the bit. It is intended that the seal-bearing package will be rotated and loaded by the Drilling Research Laboratory drill rig, pressing against the thrust bearing as just mentioned. An outer housing will be needed to provide mud circulation around the seal-bearing package for cooling of the outer housing. Provision will be made for regulating the mud flow, so that the temperature of the seal-bearing package can be controlled by varying the amount of mud that is recirculated along the entire length of the seal-bearing package outer housing.

This design will allow for elevated temperature tests to the desired temperature of about $250^{\circ} \mathrm{F}$ without extensive heaters in that self-generated heat from the seals and bearings will provide the necessary heating. A simple seal will be needed around the drill stem as shown in the Figure, to provide a slight pressure build-up around the housing which will prevent the mud from boiling in the $250^{\circ} \mathrm{F}$ environment. The mud flow circulating around the length of the housing may have to be cooled before being depressurized at the choke to avoid 
boiling the drilling mud. Based on past experience, the low pressures required to prevent boiling ( 30 psia) should not pose any serious sealing problem.

The test facility will include a high frequency actuator connecting the drilling rig drill stem and the seal-bearing package sub. The high frequency actuator will be used to provide the dynamic, high frequency loading to the seal-bearing package as well as transmitting loads to simulate the full-bit weights of 60,000 pounds. The actuator will be capable of frequencies up to 10 hertz with load amplitudes to two times average bit weight. The actuator will be able to simulate rough drilling conditions where an actual seal-bearing sub would experience loads varying up to twice the normal bit weight. The seal-bearing package is designed to carry loads in either direction; however, in these tests, loads only in one direction, i.e., downward, will be tested. (The bearing packs will be symmetrical, therefore, loading the bearing in only one direction should be adequate.)

The design will include all of the necessary instrumentation to measure the quantities outlined in Table III below. 
TABLE III

Instrumentation for Seal-Bearing Package

Measurements

Bearing temperature

Temperature of seal

Lubrication temperature
Approximate Location

Vicinity of the bearing in outer housing

In the vicinity of the lower part of each seal package in the outer housing

Temperature in the lubricant near the bearing and near the rotary seal

Lubricant extraction port In the vicinity of bearing

Lubricant quantity monitor As is possible, in the vicinity of the floating piston 
A provision for bringing electrical leads out of the pressure environment will allow the data to be recorded continuously as the test is performed. The instrumentation and subsequent monitoring of parameters is an important part of the test, since the seal-bearing package is intended to be reusable. It is important that it not be destroyed by overheating to the point that it cannot be rebuilt for subsequent tests on seals and bearings.

The choke needed for providing an effective pressure drop across the bit will require some additional design; however, previous experience gained in the Drilling Research Laboratory high-pressure drilling experiments (using mud chokes to pressures of $5,000 \mathrm{psi}$ ) suggests that the choke problem can be solved with a reasonable effort. It is expected that either a hard steel or tungsten carbide choke will be used in the range of 1,500 to 2,000 psi pressure drop. Adequate mud pumping equipment is already in operation in the Drilling Research Laboratory as well as mud mixing, storage and analysis capabilities.

\section{TEST DETAILS FOR THE INITIAL SEAL-BEARING PACKAGE TESTS}

The following summarizes plans for the initial tests using the test set-up described above. As stated, the tests will be performed in the Drilling Research Laboratory. During the tests, the rotary rig will provide the rotation and thrust to the seal-bearing package, and the mud pumps will circulate the necessary drilling fluid. Realistic drill bit pressure drops, 1,500 to 2,000 psi, will be used during the tests, and the ambient temperature in the cell will be maintained at about $250^{\circ} \mathrm{F}$ around the seal-bearing sub. 
The seal-bearing package will be tested to seal failure, or to eminent seal or bearing failure based on temperature measured in the seal-bearing package, or until lubricant supply is nearly exhausted, or until lubricant degradation measurements indicate that failure is eminent. Every attempt will be made not to destroy the seal-bearing package so that it can be reused, although tests to near failure are required. A preliminary test matrix as indicated below will be conducted.

\section{TABLE IV}

Tentative Initial Test Matrix for Bearing-Seal Package

Test Parameters

\begin{tabular}{ccccccc} 
Test Number & $\begin{array}{c}\text { Type } \\
\text { Seals }\end{array}$ & $\begin{array}{c}\text { Type } \\
\text { Bearings }\end{array}$ & $\begin{array}{c}\text { Fixed } \\
\text { Conditions* }\end{array}$ & $\begin{array}{r}\text { Pre-** } \\
\text { Temperature } \\
\text { Soak }\left({ }^{\circ} \mathrm{F}\right)\end{array}$ & $\begin{array}{c}\text { Dyanmic } \\
\text { Load }\end{array}$ \\
\cline { 1 - 2 } 1 & 1 & Roller & Yes & None & Yes \\
2 & 1 & Roller & Yes & 400 & Yes \\
3 & 1 & Roller & Yes & 400 & No \\
4 & 1 & Ball & Yes & 400 & Yes
\end{tabular}

$1=$ The seals selected from those tested in the seal tester will be used for all tests.

* Fixed conditions proposed are $500 \mathrm{RPM}, 250^{\circ} \mathrm{F}$, pressure drop of 1,500 psi across seals.

** The soaking operation performed will be done by preheating the seal-bearing package to the desired temperature for the desired length of time away from the Drilling Research Laboratory drill stand. Soaking will be done without mud flow and without load on the seals and bearings to simulate the tripping operation, or high-temperature soaking where the motor might sit on the bottom of a geothermal well without circulation due to pump failure. 
After each test the seal-bearing package will be dismantled, seals and bearings removed and replaced with an appropriate combination as is necessary. The seals and bearings will be retained for further analysis.

During the tests, small quantities of lubricant will be extracted for analysis at intervals equal to about 10 percent of the estimated life. After each of the five tests, the seal-bearing package will be disassembled and rebuilt, utilizing new seals and bearings.

After the initial series of tests, refinements can be made as required to improve the test stand. In addition, these tests should provide valuable insight for possible modifications of test parameters for following tests. 
CONCLUSIONS

There are serious limitations in currently available downhole motors that restrict their use to specialized applications, such as directional drilling even for low temperature oil and gas wells. The main problems causing these limitations are:

- Short bearing life due to inadequate or short seal iife, even at undesirably low pressure drops across the bit.

- High rotational speed.

For geothermal applications, an added problem exists:

- All elastromeric components degrade very rapidly at even very modest temperatures.

Significant progress has been made during this effort toward finding solutions to the seal-and-bearing problems.

+ A seal-test facility has been designed and built to test fullscale seals for downhole motors. The tests will simulate closely the environment imposed on seals used in actual motor drilling. This facility will greatiy reduce the time and money needed to develop an improved seal for downhole motors (as well as other geothermal applications).

+ Many seal designs and concepts have been considered, including novel designs and modifications to conventional seal types. Several of the most promising designs (including some novel designs) have been designated for testing in Phase II. Some of these seals have already been obtained and are available for testing. 
+ The preliminary design for a seal-bearing package test stand has been completed. This facility will allow tests of full-size seal-bearing packs at simulated downhole conditions.

+ The design of a new seal-bearing package has been completed and is scheduled for full-scale testing in Phase II. This package will allow worn seals and bearings to be replaced easily, (eventually even in field applications).

+ New thrust bearings have been selected for application in the sealbearing package. These bearings offers much greater load capacity and should increase bearing life significantly.

During Phase II of this program, tests will be performed on candidate seals as well as on seal-bearing combinations to determine an optimum configuration for a replaceable seal-bearing package. Testing of this optimized package in the seal-bearing test stand is also planned for Phase III. The completion of a reliable seal-bearing package for use in downhole drilling motors will mark a major accomplishment in the effort to make these tools an economically feasible alternative. 
All iquander, 0., 1968, Das Moderne Rotary Bohren, VEB Deutscher Verlag fur Grundstoffindustrie, Leipzig, Germany.

Asti, F. J., 1976, "Perfluoroelastomer For Seals in Natural Energy Production Applications," 51 st Annual SPE Fall Meeting, New Orleans, Oct. 3-6.

Baker, M. C. and Baker, C. E., 1884, "Machine for Operating Drills," U. S. Patent No, 292,888, Feb 5 .

Bannister, C. E., 1934, "Fluid Motor," U. S. Patent No. 1,965,564, July 10.

Bannister, C. E., 1968, "Drilling System," U. S. Patent No. $3,381,766$, May 7 .

Baumeister, T. and Marks, L. S., 1967, Standard Handbook for Mechanical Engineers, Lubricants and Lubrication, p. 6-243 to 6-258, McGraw-Hilit.

Bearings, Machine Design, Section 5 - Lubricants, June 20, 1974.

Berryman, W. 0., 1974, "Fluid Actuated Down-Hole Drilling Apparatus,"

U. S. Patent No, $3,840,080$, Oct. 8 .

Capeliuschnicoff, M. A., 1928, "Apparatus for Boring Wells and the Like," U. S. Patent No, 1,681.094, Aug. 14.

Capeliuschnicoff, M. A., 1931, "Well Drilling Tool," U. S. Patent No. 1,790,460, Jan. 27 .

Csandy, G. T., Theory of Turbo Machines, Mc-Graw Hi11, 1964.

Clark, W., 1959, "Well Drilling Apparatus and Method,"

U. S. Patent No. 2,898,087, August 4 .

Clark, W. , 1963, "Well Drilling Apparatus," U. S. Patent No. $3,112,801$, Dec. 3 .

Composite Catalogue of 0il Field Equipment and Services, published by World 0il, Gulf Publishing Company, 32nd revision 1976-77.

Cross, C. G., 1873, "Drills for Boring Artesian Wells," U. S. Patent No. 142,922, Sept. 23. 
Cullen, R. H., 1963, "Fluid Driven Motor," U. S. Patent No. $3,088,529$, May 7 .

Cullen, R. H., Elliott, C. H., Aker, J. R., and Gilchrist, T. J., 1966, "Well Drilling Apparatus," Patent No. 3,297,230.

Deily, F. H., et a1: "Downhole Measurements of Drill String Forces and Motions," Translation, ASME Journal of Engineering for Industry, May, 1968.

Dicky, L., 1972, "Thrust Bearings for Underground Drilling Engines," Patent No. 3,659,662, May 2 .

Fafnir Aerospace Bearings; The Fafnir Bearing Company, New Britian, Conn. 06050, 1973.

Faires, V. M. 1965, Design of Machine Elements, Mcmillan Company, New York.

Fox, F. K., 1972, "Rotary Drilling To01," U. S. Patent No. $3,656,565$, Apri1 18.

Fox, F. K., 1976, "Well Drilling Tool," Patent No. 3,971,450, July 27.

Futler, D. D., 1966, Theory and Practice of Lubrication for Engineers, John Wiley \& Sons.

Garrison, M. A., 1958, "Deep Well Motor Dril1," U. S. Patent No. $3,076,514$, Feb. 5 .

Garrison, M. A., 1971, "Variable Speed Motor Dril1," U. S. Patent No. $3,594,106$, July 20 .

Gilreath, L. E. and Pollard, C. H., 1969, "Hydraulically Powered Drilling Sub," U. S. Patent No. 3,435,732, Apri1 1.

Gottker, A., 1959, "Druckwassergespister Antrieb Fur Bohmeissel, Inbesondere fur Tiefbohrungen," German Patent No.

1,025,359, Apri1 16.

Gruber, J., 1960, "Electrobohrer fur Tiefbohrzievecke," German Patent No. 1,081,844, Nov. 10. 
Heilhecker, J. K., Maurer, W. C., and Lock, E. H., 1973,

"Swive1," Patent No. 3,736,007, May 29.

Holzbock, W. G., Hydraulic Power and Equipment, Industrial Press, Inc., 1968.

Iaonesian, J. R. and Iaonesian, R. A., 1968, "Fluid Multiplier Turbodrill," Patent No. 3,362,488, Jan. 9.

Iaonesian, J. R. and Iaonesian, R. A., 1968, "Well Drilling System," U. S. Patent No. 3,362, ,488, Jan 9.

Iaonesian, J. R. and Kuzin, B. V., 1976, "Thrust Support for a Fluid Motor Used in Drilling Wells," Patent No. $3,944,303$, March 16 .

Kern, L. R., 1973, "Bearing Device and Method for Same,". Patent No. 3,720,271, March 13,.

Kern, L. R. and Striegler, J. H., 1973, "Drilling Tools and Bearing System," Patent No. 3,722;609, March 27.

Kern, L. R. and Striegler, J. H., 1974, "Downhole Drilling Tool and Seal Assembiy," Patent No. 3,807,513, April 30.

Lee, R. L., 1932, "Mechanism for Drilling Angular Channels," U. S. Patent No. 1,850,403, March 22.

Maurer, W. C., Miller, J. F. and Hickman, I. D., 1973, "Swivel," Patent No. 3,752,507, Aug. 14:"

Ogly, A. A., Baldenko, D. F., Gusman, T., Kochnev, A. M. and Nikomarov, S. S., 1974, "Multistart Helical Rótor Mechanism," Patent No. 3,822,972, July, 9.

Peterson, C. R., 1974, "Downhole Hydraul ic Motor Suitable for Roller Bits," Patent No, 3,838,953, Oct. 1.

Pippenger, T. J., Industrial Hydraulics, Mc-Graw Hill Book Company, 1970 .

Precision Bearings, 1975, Handbook H-80A, McGill Manufacturing Company, Inc., Valparaiso, Indiana, 46383, March.

"Program to Develop Improved Downhole Drilling Motors," Terra Tek Technica1, Report No. TR 76-59, November, 1976. 
"Proposal for Improvement of Downhole Drilling Motor Bearings and Seals," Terra Tek Proposal No. P77-01, January, 1977.

Ratcliff, G. H., 1969, "The Whittle Turbodrill," Journal of the Institute of Petroleum, Vol. 55, p. 71, March.

Roller Thrust Bearings, 1969, Andrews Bearing Corporation, Spartanburg, South Carolina, 29304.

Scharpenberg, C. C., 1924, "Fluid Operated Well Drilling Apparatus," U. S. Patent No. 1,482,702, Feb. 5.

SKF Product Catalogue, 1971, Catalogue 450A, SKF Industries, Incorporated, Philadelphia, Pa.

SKF Product Cata logue, 1974, Catalogue 450B, SKF Industries, Incorporated, Philadelphia, Pa.

Striegler, J. H., 1973, "Drilling Tool and Bearing System," Patent No. 3,730,284, May 1 .

Tirapolsky, W. and Rouviere, R. F., 1960, "Revoluble Engines and Motors for Subterranean Drilling," U. S. Patent No. $2,952,494$, Sept. 13 .

Tirapolsky, W. and Rouviere, R., 1969, "Ball Thrust Bearing for Driving Shaft Subjected to Axial Thrust, Particularly for Turbodrill Shaft," Patent No. 3,449,030, June 10.

Tirapolsky, W. and Rouviere, R., 1962, "Motor for Subterranean Work," Patent No. 3,039,735, June 19.

Tirapolsky, W., Cresson, V. and Rouviere, R. F., 1962, "WellDrilling Turbines," U. S. Patent No. 3,058,510, Oct. 16.

Torrington Bearings, Catalogue 1269, The Torrington Company, South Bend, Indiana 46627, 1873.

Tschirky, J. E., 1975, "In-Hole Motors," Patent No. 3,894,818, July 15.

Warder, C. E., 1975, "Hydraulic Rotary Well Drilling Machines," Patent No. 3,876,350, April 8.

Whittle, F., 1960, "High-Speed Turbo-Drill with Reduction Gear," U. S. Patent No. 2,937,008.

Yost, L., 1942, "Radial Ball Bearing," Patent No. 2,286,528. 